\title{
Veterinary Drug Residues in Animal-Derived Foods: Sample Preparation and Analytical Methods
}

\author{
Bo Wang ${ }^{1}$, Kaizhou Xie ${ }^{2,3, *}$ and Kiho Lee ${ }^{4, *(D)}$ \\ 1 College of Veterinary Medicine, Yangzhou University, Yangzhou 225009, China; dz120180009@yzu.edu.cn \\ 2 Joint International Research Laboratory of Agriculture \& Agri-Product Safety, Yangzhou University, \\ Yangzhou 225009, China \\ 3 College of Animal Science and Technology, Yangzhou University, Yangzhou 225009, China \\ 4 College of Pharmacy, Korea University, Sejong 30019, Korea \\ * Correspondence: kzxie@yzu.edu.cn (K.X.); kiholee@korea.ac.kr (K.L.); \\ Tel.: +86-139-5275-0925 (K.X.); +82-44-860-1616 (K.L.)
}

check for updates

Citation: Wang, B.; Xie, K.; Lee, K. Veterinary Drug Residues in Animal-Derived Foods: Sample Preparation and Analytical Methods. Foods 2021, 10, 555. https://doi.org/ $10.3390 /$ foods 10030555

Received: 10 February 2021

Accepted: 4 March 2021

Published: 7 March 2021

Publisher's Note: MDPI stays neutral with regard to jurisdictional claims in published maps and institutional affiliations.

Copyright: (c) 2021 by the authors. Licensee MDPI, Basel, Switzerland. This article is an open access article distributed under the terms and conditions of the Creative Commons Attribution (CC BY) license (https:// creativecommons.org/licenses/by/ $4.0 /)$

\begin{abstract}
Veterinary drugs are used to treat livestock and aquatic diseases and thus are introduced into animal-derived foods, endangering consumer health and safety. Antibiotic resistance is rapidly becoming a major worldwide problem, and there has been a steady increase in the number of pathogens that show multi-drug resistance. Illegal and excessive use of veterinary drugs in animals and aquaculture has serious adverse effects on humans and on all other environmental organisms. It is necessary to develop simple extraction methods and fast analytical methods to effectively detect veterinary drug residues in animal-derived foods. This review summarizes the application of various sample extraction techniques and detection and quantification methods for veterinary drug residues reported in the last decade (2010-2020). This review compares the advantages and disadvantages of various extraction techniques and detection methods and describes advanced methods, such as those that use electrochemical biosensors, piezoelectric biosensors, optical biosensors, and molecularly imprinted polymer biosensors. Finally, the future prospects and trends related to extraction methods, detection methods and advanced methods for the analysis of veterinary drug residues in animalderived foods are summarized.
\end{abstract}

Keywords: veterinary drugs; animal-derived foods; extraction; detection methods; advanced methods; residues

\section{Introduction}

Veterinary drugs are substances or mixtures used for the prevention, treatment, or diagnosis of animal diseases or for purposeful regulation of animal physiological functions [1]. During recent decades, different types of veterinary drugs have been used in animals and aquaculture for high-yield production. Veterinary drugs have indeed been used to treat some diseases of farm animals, such as poultry, pigs, and cattle, but longterm use of veterinary drugs has caused drug resistance in animals [1]. In the process of aquaculture, the use of veterinary drugs can easily lead to water environmental pollution and affect the safety of drinking water. Excessive and illegal use of some veterinary drugs poses a severe threat to human health and causes environmental pollution, leading to the death of some animals, plants, and microorganisms [2-4]. Veterinary drug residues have become a hot issue, and various countries are advocating the reduced use of antibiotics and development of new alternative veterinary drugs to minimize the harm caused by veterinary drug residues.

To date, veterinary drugs are still used to treat diseases in farmed animals and in aquaculture. Veterinary drugs are introduced to the animal's body through three routes-via animal feed, oral administration, or injection — and most are added to the feed. Veterinary drugs are metabolized by animals, and some of the drugs remain in the animal body, while 
others enter the environment through excreta. In aquaculture, veterinary drugs usually enter fish, shrimp, and crabs as well as other aquatic products and rivers. The veterinary drugs in these excretions and in rivers are absorbed by vegetables and by fruit trees. Humans drink water and eat vegetables and fruit containing veterinary drugs. These drugs re-enter the body and seriously endanger human health. We summarized the information on veterinary drug residues in the environment and animal-derived foods in Figure 1. To protect the health and safety of consumers, the European Union (EU), United States, China, and other countries have established maximum residue limits (MRLs) for veterinary drugs in animal-derived foods [5-7].

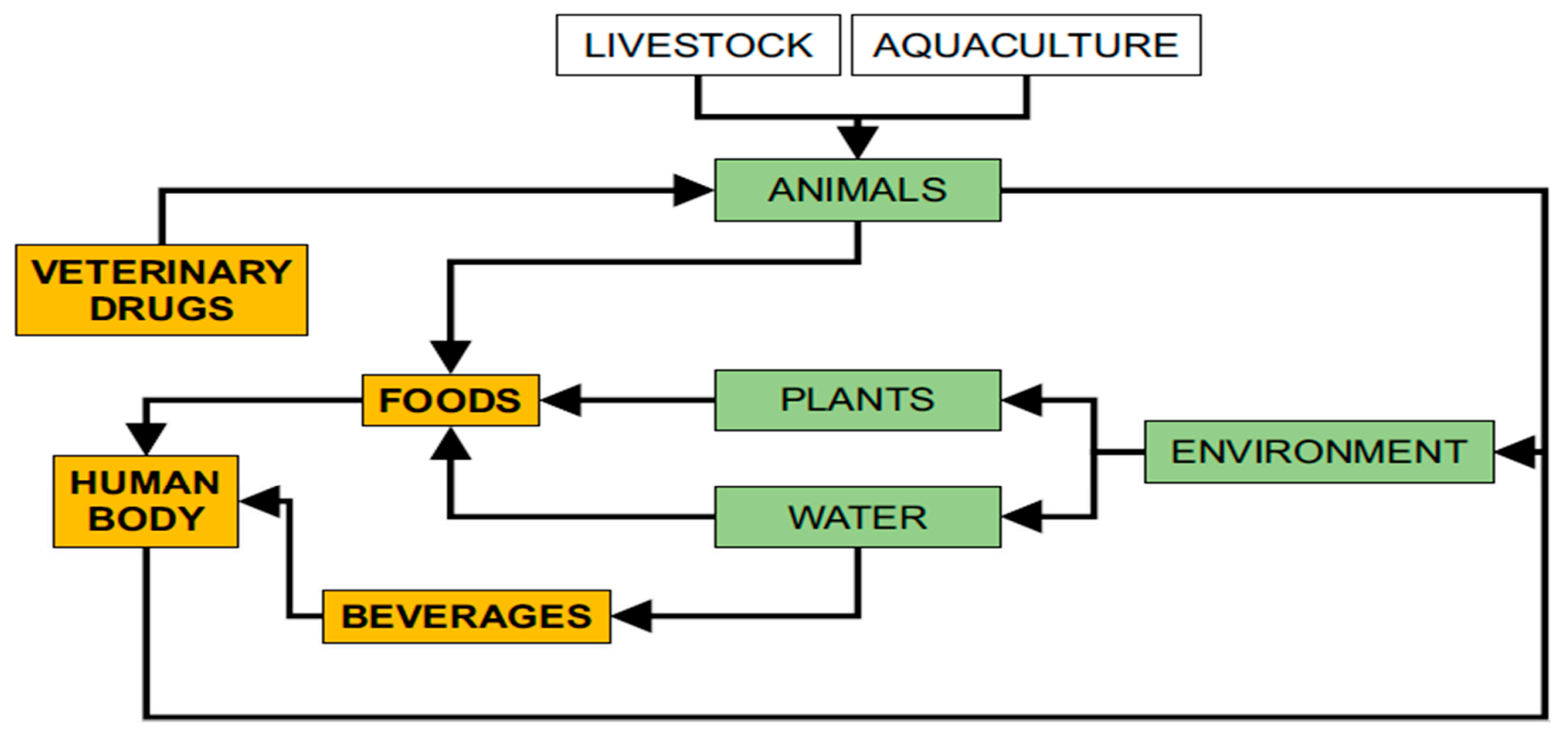

Figure 1. A series of processes involving veterinary drug residues in the human body.

The use of veterinary drugs has rapidly increased, mainly in farm animal breeding and aquaculture, allowing high-yield and high-quality production of animal-derived foods [8]. However, excessive use of these drugs leads to harmful residues, including metabolites and original drugs, which can endanger animal and human health. Qualitative and quantitative analyses of these drugs are needed to ensure the safety of animal-derived food and combat illegal and excessive use of veterinary drugs in the animal breeding industry. Therefore, many detection techniques have been developed to detect veterinary drug residues in animal-derived foods. Currently, the classic analysis methods commonly used for veterinary drugs include enzyme-linked immunosorbent assay (ELISA) [9], capillary electrophoresis (CE) [10], liquid chromatography (LC) [11] and gas chromatography (GC) [12]. Generally, these methods have high sensitivity and selectivity in the detection of animal-derived foods. Due to the complexity of the matrix, a sample pre-treatment process is usually required before instrument testing. The methods for extracting veterinary drugs from animal-derived foods mainly include liquid-liquid extraction (LLE) [13]; solid-phase extraction (SPE) [14]; accelerated solvent extraction (ASE) [15]; quick, easy, cheap, effective, rugged and safe (QuEChERS) extraction [16]; matrix solid-phase dispersion (MSPD) extraction [17]; ultrasound-assisted extraction (UAE) [18] and solid-phase microextraction (SPME) [19]. However, traditional detection methods combined with these sample pre-processing techniques are limited by disadvantages such as cumbersome operations, large time costs, and expensive instruments. The second approach is to detect veterinary drug residues in animal-derived foods via advanced devices based on sensing principles, including electrochemical biosensors, piezoelectric biosensors, optical biosensors, and molecularly imprinted polymer (MIP) biosensors [20,21]. Compared with traditional detection methods, advanced methods have the advantages of being fast, simple, low 
cost, highly sensitive, and highly selective, but the limit of detection of the sensor cannot reach the same level, and the quantitative accuracy is not as good as that of traditional detection methods.

The detection of veterinary drug residues in animal-derived foods is very important. Therefore, this article briefly describes the classification, use and physicochemical characteristics of veterinary drugs, sample preparation techniques, comparison of traditional detection methods and introduction of advanced methods in the past decade (2010-2020). The purposes of this review are to provide insight into the research progress of the detection methods of veterinary drug residues in animal-derived foods and to compare the advantages and disadvantages of different detection methods so that researchers can choose the appropriate method for further research.

\section{Veterinary Drugs: Classification, Use and Physicochemical Characteristics}

Veterinary drugs are classified according to their source, use, and chemical structure and can be classified as natural drugs, semi-synthetic drugs, and synthetic drugs. According to their use, veterinary drugs can be roughly classified into four categories: general disease control drugs, infectious disease control drugs, internal and external parasitic disease control drugs, and growth-promoting drugs. Generally, researchers classify compounds according to their structure and function, such as antimicrobials, corticosteroids, analgesics, anti-parasitics and hormones. This article will introduce the use, antibacterial mechanism, and toxicity of nine types of veterinary drugs: penicillins (PCNs), amphenicols (APs), macrolides (MACs), aminoglycosides (AGs), quinolones (Qs), tetracyclines (TCs), lincosamides (LAs), sulphonamides (SAs) and coccidiostats (COCs). The structures of representative compounds from each class of drugs studied are shown in (Figure 2).

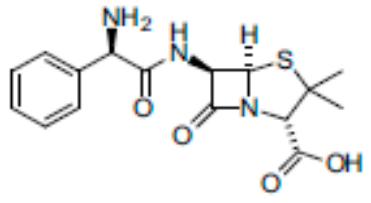

ampicillin<smiles>CNC(C)C1CCC(N)C(OC2C(N)CC(N)C(OC3OCC(C)(O)C(NC)C3O)C2O)O1</smiles>

gentamicin<smiles>CCC[C@H]1C[C@@H](C(=O)N[C@@H](CO)[C@H]2O[C@H](SC)[C@@H](O)[C@H](O)[C@H]2O)N(C)C1</smiles>

lincomycin

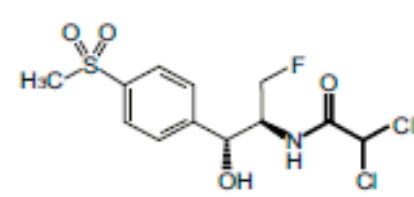

florfenicol<smiles>CCn1cc(C(=O)O)c(=O)c2cc(F)c(N3CCNCC3)cc21</smiles>

norfloxacin

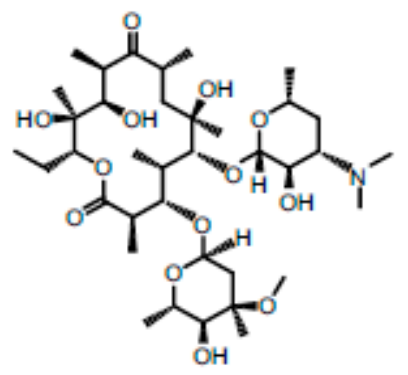

erythromycin

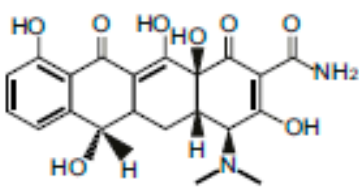

tetracycline

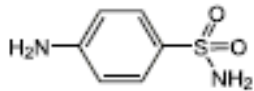

sulphanilamide

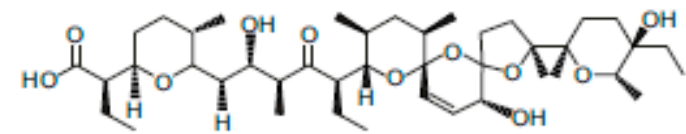

salinomycin

Figure 2. Structures of representative compounds from each class of antimicrobials used as veterinary drugs. 
PCNs are a group of antibiotics, including natural PCNs (penicillin $G, K, N, O$, and V), $\beta$-lactamase-resistant PCNs (methicillin, oxacillin, and cloxacillin), aminopenicillins (ampicillin (AMP), amoxicillin, and pivampicillin), carboxypenicillins (carbenicillin, ticarcillin, and temocillin), ureidopenicillins (mezlocillin, azlocillin, and piperacillin) and $\beta$-lactamase inhibitors (clavulanic acid, sulbactam, and tazobactam). The antibacterial mechanism of PCNs involves inhibition of cell wall synthesis by inhibiting the enzyme activity required for cross-linking of peptidoglycans in the bacterial cell wall, leading to cell lysis and death [22]. Natural PCNs cannot tolerate the enzymes produced by drug-resistant strains (such as drug-resistant Staphylococcus aureus) and are easily destroyed by these enzymes. In addition, the antibacterial spectrum of these drugs is relatively narrow, and they are mainly effective against gram-positive bacteria. PCNs can kill bacteria by interfering with the synthesis of bacterial cell walls [22]. PCNs have low toxicity, but a small number of people are allergic to these drugs, exhibiting conditions such as skin rashes, drug fever, and asthma [23].

APs are a class of broad-spectrum antibiotics, including mainly chloramphenicol (CAP), thiamphenicol (TAP) and florfenicol (FF). The antibacterial mechanism of APs involves inhibition of bacterial protein biosynthesis via control of the peptidyl transferase of bacterial ribosomes. APs are antibiotics that are useful for the treatment of several bacterial infections, which have an effect on both gram-positive bacteria and gram-negative bacteria [24]. CAP can cause serious side effects (inducing aplastic anemia), so it is listed as a banned drug by the EU [5]. TAP is a derivative of CAP but is less toxic than CAP, causing diseases such as aplastic anemia, bone marrow suppression and liver toxicity [25]. FF, as the third-generation product of CAP, has low toxicity and is still used to treat animal diseases.

MAC is a general term for a class of antibacterial drugs with 12-16 carbon lactone rings in the molecular structure, mainly including erythromycin and its ester derivatives (azithromycin and roxithromycin), clarithromycin and telithromycin. The mechanism of action of MACs involves inhibition of bacterial protein biosynthesis by preventing peptidyl transferase from adding the growth peptide linked to tRNA to the next amino acid (similar to chloramphenicol) and inhibiting ribosomal translation [26,27]. MACs can be used to treat infections caused by gram-positive bacteria, a limited number of gram-negative bacteria, and some respiratory and soft-tissue infections [28]. The toxicology of MAC antibiotics includes mainly gastrointestinal symptoms, liver toxicity, cardiotoxicity, and allergic reactions [29].

AGs are so named because their molecular structure has an amino cyclic alcohol and one or more amino sugar molecules, which are connected by glycosidic bonds to form glycosides [30]. Kanamycin A, amikacin, tobramycin, dibekacin, gentamicin, sisomicin, netilmicin, neomycin $B$, neomycin $C$, neomycin $E$, streptomycin, and plazomicin are all AG antibiotics. As antibacterial agents, AGs act on ribosomes in bacteria, inhibit protein synthesis, and destroy the integrity of bacterial cell membranes [30]. AGs show bactericidal activity against gram-negative aerobes and some anaerobic bacteria but have no resistance to gram-positive and anaerobic gram-negative bacteria [31]. The main adverse reactions of AGs are nephrotoxicity and ototoxicity, especially in children and the elderly [32,33].

Qs (e.g., pipemidic acid, oxolinic acid, and cinoxacin) and their synthetic fluoridecontaining derivatives, fluoroquinolones (FQs) (e.g., ciprofloxacin and ofloxacin), are members of a large group of broad-spectrum bactericidals that share a bicyclic core structure related to the substance 4-quinolone or 4-fluoroquinolone [34,35]. The target enzymes of Qs are bacterial DNA gyrase (gyrase) and topoisomerase IV. In most gram-negative bacteria, DNA gyrase is the main target enzyme for Qs. In most gram-positive bacteria, Qs mainly inhibit bacterial topoisomerase IV, which is a helicase that can release the entangled chromosomes of the progeny during DNA replication. Nearly all quinolone antibiotics in use are FQs, which contain a fluorine atom in their chemical structure and are effective against both gram-negative and gram-positive bacteria [36,37]. Qs and FQs can cause allergic reactions, affect cartilage development, cause liver damage, and have 
other adverse effects, especially in juvenile animals, and in children, these drugs can cause arthropathy [38].

TCs (e.g., chlortetracycline, oxytetracycline, and tetracycline) are a group of broadspectrum antibiotic compounds with a common basic structure that can be directly isolated from several species of Streptomyces, or they can be obtained by semi-synthesis [39]. The mechanism of action of TCs is that the drug can specifically bind to the A position of the $30 \mathrm{~S}$ subunit of the bacterial ribosome to prevent the connection of aminoacyl-tRNA at this position, thereby inhibiting the growth of peptide chains and affecting the synthesis of bacterial proteins [40]. TCs have a broad antibacterial spectrum and have antibacterial effects on gram-positive and gram-negative bacteria, rickettsiae, spirochetes, mycoplasma, chlamydia, and certain protozoa [41]. TCs can cause liver damage, exhibit nephrotoxicity, are not conducive to bone and tooth growth, and cause gastrointestinal reactions [42,43].

LAs are a class of powerful, narrow-spectrum antibacterial drugs produced by Streptomyces and include lincomycin, clindamycin, and pirlimycin [44]. As antibacterial agents, LAs prevent bacterial replication by interfering with protein synthesis and have an antibacterial effect on most gram-positive bacteria and some anaerobic gram-negative bacteria [45]. LAs are usually used clinically as alternative antibiotics for patients allergic to penicillin. In veterinary microbiology, LAs are used as first-line antibiotics to combat skin infections [46]. The toxicology of LAs causes gastrointestinal dysfunction, allergic reactions, leukopenia and thrombocytopenia [47].

SAs (e.g., sulphanilamide, acetohexamide, and ethoxzolamide) are a group of synthetic drugs containing sulphonamide chemical groups and are the first widely used antibacterial agents to be systematically used [48]. According to clinical use, sulpha drugs can be divided into three categories: sulpha drugs that are easily absorbed in the intestine, sulpha drugs that are difficult to absorb in the intestine, and sulpha drugs for external use. As antibacterial agents, SAs act as competitive inhibitors of dihydropterin synthase (DHPS, an enzyme involved in folic acid synthesis), which can inhibit the growth and reproduction of bacteria [49]. SAs are used to treat allergies and coughs, as well as antifungal and antimalarial functions. The toxicology of SAs mainly includes allergic reactions, kidney damage, hematopoietic effects, and central nervous system and gastrointestinal reactions $[50,51]$.

COCs used as anti-coccidials come from several different drug classes, including nitroimidazoles, ionophores, triazines, benzamides, carbanilides, quinolone derivatives, and other anti-coccidials [52]. COCs have four possible mechanisms of action: they affect ion transport through cell membranes, affect coenzyme absorption and synthesis, affect mitochondrial function and act on plastids. COCs have effects on both gram-positive bacteria and gram-negative bacteria, which are widely used to prevent poultry breeding $[53,54]$. Since COCs are generally used for a long time, residues in meat and eggs are inevitable, often affecting product quality and human health. Therefore, it is necessary to strictly enforce the withdrawal period for COCs.

After these drugs enter the animal body, they undergo physical and chemical reactions and finally remain in the meat, milk, eggs and animal tissue food as the original drug or metabolites. In addition, the original drug or metabolites are discharged into the environment through excrement. The study of drug metabolism of antibiotics in different animals involves pharmacokinetic studies. A well-developed detection method is conducive to the study of pharmacokinetics and drug elimination rules to determine the withdrawal period and time to market.

\section{Extraction Methods}

Generally, the detection of veterinary drug residues in animal-derived foods requires sample pre-processing, instrumentation method establishment and data analysis to evaluate the stability, precision, and sensitivity of the established method. Animal-derived food samples have a complex matrix and many endogenous interfering substances, making it impossible to directly detect veterinary drug residues. Before sample testing, sam- 
ple pre-treatment steps such as extraction, purification, evaporation, concentration, and reconstitution are usually required.

\subsection{Liquid-Liquid Extraction (LLE)}

LLE is a traditional sample pre-treatment method that includes solvent extraction and ultrasonic vibration-mediated extraction. Different extraction reagents are used to extract veterinary drug residues from animal-derived foods, including acetonitrile (ACN) $[55,56]$, ethylenediaminetetraacetic acid disodium salt (EDTA)-succinate [57], 0.1\% formic acid in aqueous solution of EDTA $0.1 \%(w / v)-A C N-$ methanol $(\mathrm{MeOH})(1: 1: 1, v / v)$ [58], acidified methanol 1\% HCOOH [59] and ethyl acetate-ACN-ammonium hydroxide (49:49:2, v/v) [60].

Recently, Xie et al. [60] reported an LLE method combined with a high-performance liquid chromatography-tandem triple quadrupole mass spectrometry (HPLC-MS/MS) analytical system to detect CAP, TAP, FF, and FF amine in egg samples. The limit of detection (LOD) and limit of quantification (LOQ) were $0.04-0.5 \mu \mathrm{g} / \mathrm{kg}$ and $0.1-1.5 \mu \mathrm{g} / \mathrm{kg}$, respectively, and the extraction recovery rate was $90.84-108.23 \%$, with relative standard deviations (RSDs) of less than $9.61 \%$ and correlation coefficients $\left(R^{2}\right)$ exceeding 0.9994 . The developed method has shown good sensitivity and recovery rates. Dasenaki and Thomaidis [58] extracted 115 veterinary drugs from milk powder, butter, fish tissue and eggs using the LLE method prior to LC-MS/MS. The LLE-LC-MS/MS method showed low LODs and LOQs ranging from $0.008 \mu \mathrm{g} / \mathrm{kg}$ to $3.15 \mu \mathrm{g} / \mathrm{kg}$ with a correlation $\mathrm{R}^{2}$ value exceeding 0.99 , and the RSD values obtained were less than $18 \%$. In another study, conducted by Tang et al. [55], an efficient, fast, and convenient method based on LLE and ultra-performance liquid chromatography (UPLC)-MS/MS was developed for the determination of 23 veterinary drugs in milk with LOD values from $0.1-2.5 \mathrm{ng} / \mathrm{mL}$.

Chung and Lam [56] developed ultra-performance hydrophilic interaction LC (HILIC) and reversed-phase LC (RPLC) coupled to an MS/MS spectrometer for the simultaneous detection of 15-class veterinary drugs in milk, egg, and meat. The proposed HILIC-MS/MS and RPLC-MS/MS methods coupled with LLE are simple and efficient extraction and detection techniques that can detect recovery values ranging between $70 \%$ and $120 \%$ in milk, egg and meat samples with good precision and linearity. The LLE method has been used to extract veterinary drug residues from animal-derived foods for nearly a decade. The method is simple in operation but has disadvantages such as high reagent consumption, time consumption and chance of manual error. Moreover, toxic organic solvents are usually used in the LLE extraction process, as researchers must take protective measures to avoid physical harm.

\subsection{Solid-Phase Extraction (SPE)}

SPE is a fast and selective sample preparation and purification technique that is performed before chromatographic analysis. SPE technology allows sample purification, recovery, and concentration for precise quantitative analysis. The principle underlying the selectivity of SPE is similar to that of LC. Compared with the traditional LLE method, SPE can improve the recovery rate of the analyte, separate the analyte from the interfering components more effectively, and reduce sample pre-treatment processing, making it simple in operation and saving time and effort [61]. Common SPE cartridges include CNWBOND LC-C18 SPE cartridges [61], EVOLUTE ABN SPE cartridges [62], hydrophiliclipophilic balance (HLB) SPE cartridges [63-67], and hybrid SPE cartridges [68], which are used to extract veterinary medicines from meat, milk, eggs, honey, fish, shrimp, eel, and animal tissues.

Recently, Wang et al. [61] applied CNWBOND LC-C18 SPE cartridges to extract eight kinds of COCs (robenidine, halofuginone, lasalocid, monensin, nigericin, salinomycin, narasin, and maduramicin) from egg samples. The CNWBOND LC-C18 SPE cartridge has unique selectivity, and the long carbon chain also exhibits strong non-polarity. Because of its relatively low carbon content, it is more suitable for retaining polar compounds or non-polar compounds that are too large. HPLC-MS/MS and UPLC-MS/MS methods were 
used to determine and quantify these compounds. The recoveries of the two methods were more than $71.7 \%$, and the LOD values $(0.16-0.52 \mu \mathrm{g} / \mathrm{kg})$ were lower than the MRLs of these drugs. Another study conducted by Kaufmann et al. [62] analyzed more than 100 different veterinary dugs from various food matrices (muscle, kidney, liver, fish, and honey). This study compared OASIS HLB SPE cartridges and ABN SPE cartridges, and the results showed that $\mathrm{ABN}$ SPE cartridges achieved good extraction recovery. SPE technology combines UPLC with high-resolution mass spectrometry (HRMS) to quantitatively detect these analytes, and the LOD $(1 \mu \mathrm{g} / \mathrm{kg})$ of these analytes is much lower than the value set by the EU. The development of this method has greatly improved the detection efficiency, and more than one hundred drugs can be measured simultaneously.

Dasenaki et al. [63] used HLB SPE cartridges combined with UPLC quadrupole timeof-flight mass spectrometry (QTOF-MS) to extract and detect 143 veterinary drugs from milk and fish tissue. The QTOF-MS instrument can simultaneously detect more than one hundred compounds and can accurately analyze these compounds quantitatively and qualitatively. This study uses the SPE method to effectively extract milk samples, which can reduce matrix effects and enhance sensitivity. A study by Piatkowska et al. [68] used zirconium-coated silica as an SPE sorbent to extract 13 classes of veterinary drugs. The obtained recoveries of egg samples were more than $75 \%$ among all veterinary drugs, and the correlation $\left(R^{2}\right)$ value was more than or equal to 0.99 . The RSDs of the repeatability and reproducibility were $1.6-15.9 \%$ and $2.6-15 \%$, respectively. The choice of SPE cartridge is one of the important factors that affect the extraction recovery from animal-derived food samples. As shown in Table 1, this article compares the efficacy of different cartridges for veterinary drugs in animal-derived foods. CNWBOND LC-C18 SPE cartridges can effectively extract eight COCs from eggs, and EVOLUTE ABN SPE cartridges, OASIS HLB SPE cartridges and Hybrid SPE cartridges can simultaneously extract multiple residues of veterinary drugs from animal-derived foods. Because of the good extraction efficiency of OASIS HLB SPE cartridges, they are widely used for veterinary drug residues in animalderived foods [12,63-67]. The SPE method is widely used in the extraction of veterinary drug residues from animal-derived foods. Efficient and simple extraction technology is conducive to the extraction of multiple residues. In addition, LLE and SPE are often used in combination to better enrich and purify veterinary drugs in animal-derived food samples.

Table 1. Comparison of the efficacy of different cartridges for veterinary drugs in animal-derived foods.

\begin{tabular}{ccccc}
\hline Animal-Derived Food & Cartridge Type & $\begin{array}{c}\text { Extraction } \\
\text { Recovery (\%) }\end{array}$ & $\begin{array}{c}\text { LOD } \\
(\mu \mathrm{gg} / \mathbf{k g} \text { or } \mu \mathrm{g} / \mathrm{L})\end{array}$ & Ref. \\
\hline Eggs & $\begin{array}{c}\text { CNWBOND LC-C18 } \\
(6 \mathrm{~mL} / 150 \mathrm{mg})\end{array}$ & $71.7-102.7$ & $0.16-0.52$ & {$[61]$} \\
\hline $\begin{array}{c}\text { Animal tissue, fish and } \\
\text { honey }\end{array}$ & $\begin{array}{c}\text { EVOLUTE ABN } \\
(3 \mathrm{~mL} / 200 \mathrm{mg})\end{array}$ & $50.0-120.0$ & $\geq 1.0$ & {$[62]$} \\
\hline Milk and fish tissue & $\begin{array}{c}\text { OASIS HLB } \\
(3 \mathrm{~mL} / 60 \mathrm{mg})\end{array}$ & - & $15.0-200$ & {$[63]$} \\
\hline Fish, shrimp and eel & $\begin{array}{c}\text { OASIS PRIME HLB } \\
(6 \mathrm{~mL} / 200 \mathrm{mg})\end{array}$ & $70.0-120.0$ & $0.15-100$ & {$[64]$} \\
\hline Dairy products & $\begin{array}{c}\text { OASIS HLB } \\
(6 \mathrm{~mL} / 200 \mathrm{mg})\end{array}$ & $67.3-106.9$ & $0.006-0.3$ & {$[65]$} \\
\hline Bovine muscle & $\begin{array}{c}\text { OASIS HLB } \\
(6 \mathrm{~mL} / 200 \mathrm{mg})\end{array}$ & $37.4-106.0$ & - & {$[66]$} \\
\hline Milk & $\begin{array}{c}\text { OASIS HLB } \\
(3 \mathrm{~mL} / 60 \mathrm{mg})\end{array}$ & $68.0-118.0$ & $0.01-5$ & {$[67]$} \\
\hline Eggs & $\begin{array}{c}\text { Hybrid SPE } \\
(1 \mathrm{~mL} / 30 \mathrm{mg})\end{array}$ & $75.0-108.0$ & - & {$[68]$} \\
\hline Note: "-" indicates not reported &
\end{tabular}




\subsection{Accelerated Solvent Extraction (ASE)}

ASE is an automated method for extraction with organic solvents under conditions of elevated temperature and pressure. Richter et al. [69] introduced ASE as a new extraction procedure that uses organic solvents to extract solids or semi-solids at higher pressures (500-3000 psi) and higher temperatures $\left(50-200{ }^{\circ} \mathrm{C}\right.$ ). The advantages of the ASE method are the small amounts of organic solvents, high speed, low matrix effect, high recovery rate and good reproducibility, and it appears as the recommended method 3545 in update III of the US EPA SW-846 methods [70]. The ASE method is widely used to extract veterinary drug residues from animal-derived foods, and a brief flowchart of ASE sample preparation is shown in Figure 3. The animal-derived food samples are placed into a mortar and added to diatomaceous earth for grinding. After being fully ground, the sample is filled into a $22 \mathrm{~mL}$ stainless steel extraction cell, and then the lid is closed. The cell is placed on the ASE350 instrument, and the sample processing program is set.

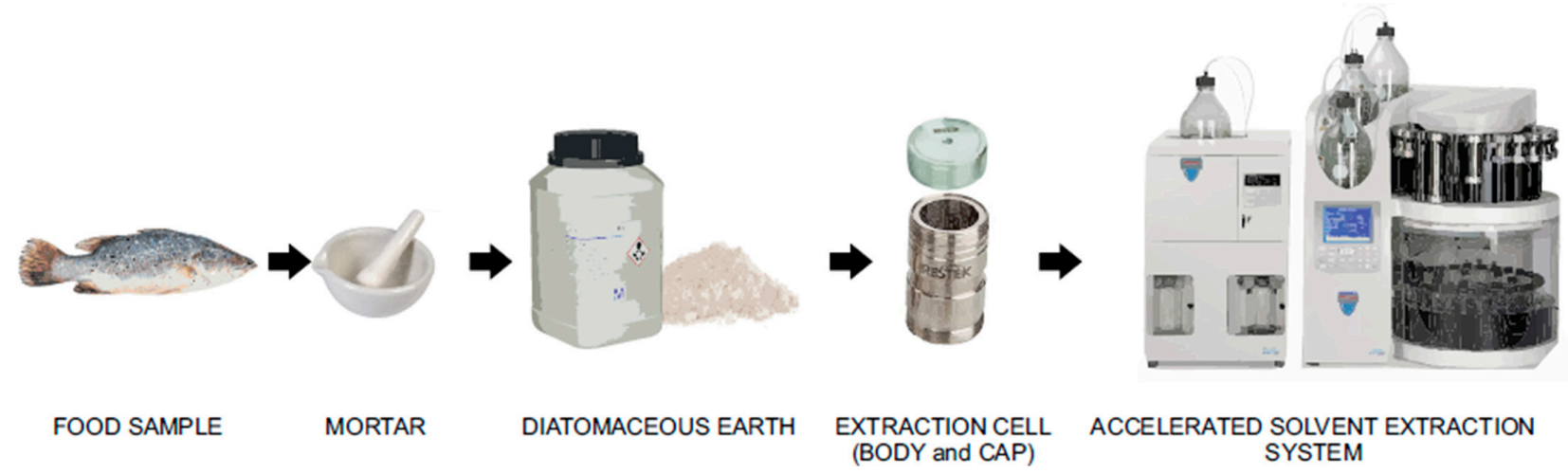

Figure 3. Flowchart of accelerated solvent extraction procedures of animal-derived food samples.

Wang et al. [12] have developed a fast and sensitive ASE method coupled with gas chromatography-tandem mass spectrometry (GC-MS/MS) for the detection of spectinomycin and lincomycin in poultry eggs. This study used an ASE350 instrument and an Oasis PRiME HLB SPE cartridge to extract and purify egg poultry samples. The proposed method successfully detected spectinomycin and lincomycin with LODs and LOQs ranging between $2.3-4.3 \mu \mathrm{g} / \mathrm{kg}$ and $5.6-9.5 \mu \mathrm{g} / \mathrm{kg}$, respectively. This method has a good correlation coefficient $\left(R^{2} \geq 0.9991\right)$, recovery (80.0-95.7\%) and precision (RSDs, 1.0-3.4\%). Compared with the ASE-HPLC-MS/MS method [11], the ASE-SPE-GC-MS/MS method involves sample preparation steps that are complicated and require solid-phase extraction, which greatly increases the processing time. Tao et al. [71] used the ASE method to extract 17 MAC and avermectin residues in swine and bovine tissues (muscle, kidney, and liver) at $60{ }^{\circ} \mathrm{C}$ and $1500 \mathrm{psi}$ for $10 \mathrm{~min}$ (static time) in two cycles, with ACN/methanol $(1 / 1, v / v)$ as the extractant. After sample preparation, this study used the LC-MS/MS method to detect these analytes. The recoveries of the samples were all higher than $75 \%$, and the LOD values were all lower than $0.55 \mathrm{~g} / \mathrm{kg}$. This study shows that ASE technology can extract multiple residues, which has advantages such as high speed, low consumption of reagents, and batch processing of samples.

Yu et al. [72] reported an ASE-HPLC-UV method for the detection of seven TCs in pig, chicken, and cattle tissues (muscle and liver). The LOD and LOQ values were lower than $10 \mu \mathrm{g} / \mathrm{kg}$ and $15 \mu \mathrm{g} / \mathrm{kg}$, respectively. Within the range of concentrations used, the sample recovery was $75.0-104.9 \%$, and the RSD was lower than $10 \%$. A novel method was proposed by Wang et al. [11], who used an ASE350 instrument for sample pretreatment with methanol-ammonium hydroxide-ultrapure water $(97: 2: 1, v / v)$ as the extractant. This study used HPLC-MS/MS to detect CAP, TAP, FF, and FF amine in poultry eggs. ASE extracts APs from poultry eggs to obtain a good extraction recovery rate, and the detection sensitivity of the method is relatively high (LOD values are all lower than $0.5 \mu \mathrm{g} / \mathrm{kg}$ ). Compared with LLE and SPE methods, ASE has the advantages of simple operation, high 
speed, and batch processing of samples, greatly improving efficiency and saving time. With the development of sample preparation technology, the automated ASE method is worthy of promotion for the extraction of veterinary drug residues from animal-derived foods.

\subsection{Quick, Easy, Cheap, Effective, Rugged and Safe (QuEChERS) Extraction}

The steps of the QuEChERS method can be simply summarized as follows: (1) crushing of the sample; (2) single-solvent (acetonitrile) extraction and separation; (3) addition of $\mathrm{MgSO}_{4}$ and other salts to remove water; (4) addition of adsorbent to remove impurities; and (5) GC-MS and LC-MS analysis of the supernatant. The QuEChERS extraction method is widely used for multi-class or multi-residue analysis of different types of veterinary drugs in animal-derived foods. The principle of QuEChERS is similar to that of HPLC and SPE. It uses the interaction between the adsorbent filler and the impurities in the matrix to adsorb impurities, thereby achieving impurity removal and purification. Anastassiades et al. [73] first proposed the QuEChERS method, which can extract both polar and non-polar compounds.

Recently, Xu et al. [74] used the QuEChERS method to extract veterinary drugs, pesticides, and mycotoxins from egg samples. The modified QuEChERS method used magnetic multiwalled carbon nanotubes $\left(\mathrm{Fe}_{3} \mathrm{O}_{4}\right.$-MWCNTs) as the adsorbent and achieved faster separation of the adsorbent by using an external magnet. Among multiple residues present in egg samples, 48 veterinary drugs, 13 pesticides and 13 mycotoxins were detected by using UPLC-MS/MS analytical systems with LOQs ranging from $0.1 \mu \mathrm{g} / \mathrm{kg}$ to $17.3 \mu \mathrm{g} / \mathrm{kg}$. The obtained recoveries were $60.5-114.6 \%$ at three fortified levels with RSDs of less than $20 \%$. Arias et al. [75] used the inexpensive and green material chitosan as an adsorbent based on the QuEChERS method to extract 7 types of veterinary drug residues from milk. Chitosan was obtained from shrimp shell waste, and the optimized QuEChERS method combined with LC-MS/MS was used to quantitatively analyse the multiple residues of veterinary drugs from milk samples with good selectivity, accuracy, and precision. The LOQs ranged between 1 and $50 \mu \mathrm{g} / \mathrm{kg}$, and recoveries ranged between 62 and $125 \%$, with an RSD $<20 \%$.

A modified QuEChERS procedure combined with the UPLC-QTOF-MS analysis method was used to detect 90 veterinary drugs in royal jelly [76]. In this method, modification of the QuEChERS procedure was performed for acid hydrolysis and protein precipitation (citric acid and $\mathrm{Na}_{2} \mathrm{HPO}_{4}$ ), including modification of extraction reagents (acetic acid-acidified acetonitrile), partitioning salts (sodium chloride-anhydrous sodium sulfate) and MSPD sorbents ( $\mathrm{NH}_{2}$ cartridges). This method achieved good correlation $\left(R^{2}\right.$, $0.9921-0.9999)$, recovery $(70.2-120.1 \%)$, precision $(1.77-9.90 \%)$, repeatability $(3.01-11.6 \%)$ and reproducibility (5.97-14.9\%). Another study based on the application of the QuEChERS method was conducted by Shin et al. [77] and detected 50 veterinary drug residues in fishery products. For the QuEChERS method, a dispersive SPE (d-SPE) method using primary secondary amine (PSA) and octadecylsilane (C18) absorbents was selected to prevent matrix interference during mass spectrometry analysis. The recoveries of 50 veterinary drugs in fishery products were $68.1-111 \%$, the RSD was $<15 \%$, and the LODs and LOQs were $<5$ and $<10 \mu \mathrm{g} / \mathrm{kg}$, respectively. The studies [78-81] indicate that QuEChERS is a simple, fast, environmentally friendly, and economical method that is suitable for the analysis of multiple residues of veterinary drugs in animal-derived food.

\subsection{Matrix Solid-Phase Dispersion (MSPD) Extraction}

Barker et al. [82] first proposed the MSPD method as a rapid sample processing technique suitable for extracting multiple drug residues from a single sample. Compared with modern extraction technology that uses high pressure and high temperature (ASE), MSPD performs the extraction process under ambient conditions and does not require any special laboratory equipment. It has advantages over conventional techniques, requiring only a few simple steps to extract a small number of samples and solvents [83]. Based on these advantages, the MSPD method is widely used in the extraction of multiple veterinary drug residues from animal-derived foods. 
Wang et al. [84] reported a novel, fast and simple mixed-template molecularly imprinted polymer (MMIP)-MSPD extraction method combined with the UPLC-photodiode array (PDA) detector analysis method to detect $8 \mathrm{FQs}, 8 \mathrm{SAs}$ and $4 \mathrm{TCs}$ in pork. The extraction procedure is based on MSPD using MMIP as a dispersant and methanol/acetic acid $(9: 1, v / v)$ as the eluent. The sample recoveries with this method exceeded $92 \%$, and the LODs of the 20 drugs in pork were $0.5-3.0 \mu \mathrm{g} / \mathrm{kg}$, which shows that this method has good sensitivity and selectivity. Another MSPD method was developed by Shen et al. [85], using HLB material as the sorbent and a pipette tip (PT) as the cartridge, to extract and purify 14 SAs from fish tissue. After the sample was processed by PT-MSPD, the eluate was analyzed by LC-MS/MS. This method is fast (5 $\mathrm{min}$ for PT-MSPD and $8 \mathrm{~min}$ for LC-MS/MS), with good recovery (70.6-95.5\%), precision (1.4-10.3\%), sensitivity (LOD, 2.3-16.4 $\mu \mathrm{g} / \mathrm{kg}$ ) and selectivity (LOQ, 6.9-54.7 $\mu \mathrm{g} / \mathrm{kg}$ ). Compared with the traditional MSPD method, the PT-MSPD method has better recovery and precision. Pan et al. [17] and Tao et al. [86] demonstrated that octadecylsilyl-derivatized silica (C18) can separate CAP, TAP and FF from fish and shrimp. Moreover, da Silva et al. [87] reported a new method that uses electrical (E)-MSPD for the extraction and clean-up of 7 FQs in bovine milk. Florisil, silica gel, or C18 can be used for sample dispersion and extraction of tetracycline, oxytetracycline and doxycycline, as previously reported by Mu et al. [88]. The blending of pork muscle samples with the Oasis HLB adsorbent has been used in the MSPD method [89]. MSPD extraction technology helps simplify the sample preparation process. Therefore, it is considered to be a simple, fast, cost-effective, and environmentally friendly method that is suitable for applications in food, animal tissues, plant material and environmental samples [90,91]. This article describes in detail the application and research progress of the LLE, SPE, ASE, QuEChERS and MSPD methods in veterinary drug residues in animal-derived foods. In addition, this article compares the advantages and disadvantages of these five extraction methods, as shown in (Table 2).

Table 2. Comparison of extraction methods for veterinary drugs (pros and cons).

\begin{tabular}{|c|c|c|}
\hline Extraction Method & Pros & Cons \\
\hline LLE & Simple, reliable, and widely applicable & $\begin{array}{l}\text { Consumption of organic reagents } \\
\text { and time consuming }\end{array}$ \\
\hline SPE & $\begin{array}{l}\text { Less time consuming than LLE } \\
\text { Good purification effect and reproducibility }\end{array}$ & $\begin{array}{l}\text { High cost of SPE cartridges } \\
\text { Requires pre-treatment and toxic } \\
\text { organic solvent }\end{array}$ \\
\hline ASE & $\begin{array}{c}\text { Low consumption of organic reagents } \\
\text { Time saving } \\
\text { Batch processing of samples } \\
\text { Automated, fast, and convenient }\end{array}$ & $\begin{array}{l}\text { High temperature and pressure, operation } \\
\text { requires professional training }\end{array}$ \\
\hline QuEChERS & $\begin{array}{c}\text { Flexible and effective } \\
\text { Simple instrumentation } \\
\text { Low reagent consumption } \\
\text { Wide scope of acidic and basic analytes }\end{array}$ & $\begin{array}{l}\text { Low enrichment factors } \\
\text { Low recovery of polar analytes }\end{array}$ \\
\hline MSPD & $\begin{array}{c}\text { Simple, efficient, and fast } \\
\text { Low reagent consumption } \\
\text { Wide scope of molecular structures and polar analytes }\end{array}$ & Relatively high degree of crushed samples \\
\hline
\end{tabular}

\subsection{Other Extraction Methods}

LLE, SPE, ASE, QuEChERS, MSPD and other types of extraction methods are used for the determination of veterinary drug residues in animal-derived foods, as summarized in Table 3. These include UAE [18], gel permeation chromatography (GPC) [92], turbulent flow chromatography (TFC) [93], fabric phase sorptive extraction (FPSE) [94], SPME [19,95], solid-liquid extraction (SLE) [96], liquid-phase microextraction (LPME) [97] and dispersive liquid-liquid microextraction (DLLME) [98]. 
Table 3. Sample preparation techniques for the detection of veterinary drugs in animal-derived food samples.

\begin{tabular}{|c|c|c|c|}
\hline Class of Veterinary Drugs & Animal-Derived Food & Sample Preparation Method & Ref. \\
\hline MACs (12), LAs (2) and other contaminants (9) & Milk & LLE: $2 \mathrm{~mL}$ fresh milk sample $+15 \mathrm{~mL}$ ACN & [55] \\
\hline $\begin{array}{c}\text { MACs (10), Qs (15), TCs (5), SAs (27) and other } \\
\text { contaminants (27) }\end{array}$ & Chicken muscle & $\begin{array}{l}\text { LLE: } 2 \mathrm{~g} \text { sample }+5 \mathrm{~mL} \text { EDTA-succinate }+10 \mathrm{~mL} \mathrm{ACN}+2 \mathrm{~g} \\
\text { sodium chloride }\end{array}$ & [57] \\
\hline $\begin{array}{l}\text { PCNs (2), APs (3), MACs (6), Qs (11), TCs (4), LAs (1), } \\
\text { SAs (18), COCs (8) and other contaminants (62) }\end{array}$ & Milk powder, butter, fish tissue and eggs & $\begin{array}{l}\text { LLE: } 1 \mathrm{~g} \text { sample }+2 \mathrm{~mL} 0.1 \% \text { EDTA in } \mathrm{H}_{2} \mathrm{O} \text { with } 0.1 \% \text { formic } \\
\text { acid }+2 \mathrm{~mL} \mathrm{ACN}+2 \mathrm{~mL} \mathrm{MeOH}\end{array}$ & [58] \\
\hline APs (4) & Eggs & $\begin{array}{l}\text { LLE: } 5 \text { g sample }+1 \mathrm{~mL} \text { ACN:water }(30: 70, v / v)+20 \mathrm{~mL} \text { ethyl } \\
\text { acetate:ACN:ammonium hydroxide }(49: 49: 2, v / v)\end{array}$ & [60] \\
\hline COCs $(8)$ & Eggs & $\begin{array}{l}\text { SPE: } 2 \text { g sample }+2 \mathrm{~mL} \text { ultrapure water }+16 \mathrm{~mL} \text { ACN: ethyl acetate } \\
(60: 40, v / v) \text { :acetic acid }(98: 2, v / v)+\text { CNWBOND C18 } 150 \mathrm{mg} \text {, elution } \\
15 \mathrm{~mL} \text { ethyl acetate }\end{array}$ & [61] \\
\hline $\begin{array}{l}\text { PCNs (7), APs (2), MACs (5), Qs (10), TCs (5), LAs (1), } \\
\text { SAs (19), COCs (13) and other contaminants (81) }\end{array}$ & Milk and fish tissue & $\begin{array}{l}\text { LLE: } 1 \mathrm{~g} \text { fish tissue sample }+2 \mathrm{~mL} 0.1 \% \text { EDTA in } \mathrm{H}_{2} \mathrm{O} \text { with } 0.1 \% \\
\text { formic acid }+2 \mathrm{~mL} \text { ACN }+2 \mathrm{~mL} \mathrm{MeOH} \text { SPE: } 2 \mathrm{~mL} \text { milk } \\
\text { sample }+16 \mathrm{~mL} 5 \% \text { trichloroacetic acid (TCA) in } \mathrm{H}_{2} \mathrm{O}: \mathrm{ACN}(3: 1, \\
v / v)+15 \% \text { ammonia hydroxide }\left(\mathrm{NH}_{3} \cdot \mathrm{H}_{2} \mathrm{O}\right)+\text { Oasis } \mathrm{HLB} 60 \mathrm{mg} \\
\text { elution } 6 \mathrm{~mL} \mathrm{MeOH}\end{array}$ & [63] \\
\hline $\begin{array}{c}\text { MACs (3), Qs (8), TCs (4), LAs (1), SAs (8) and other } \\
\text { contaminants (14) }\end{array}$ & Milk & $\begin{array}{l}\text { SPE: } 1 \mathrm{~mL} \text { sample }+0.5 \mathrm{~mL} \text { water }+3 \mathrm{~mL} \text { ACN }+3 \mathrm{~mL} 0.1 \mathrm{~mol} / \mathrm{L} \\
\text { phosphate buffer solution (PBS) + Oasis HLB } 60 \mathrm{mg} \text {, elution } 3 \mathrm{~mL} \\
\text { ACN:water }(1: 1, v / v)\end{array}$ & [67] \\
\hline AGs (1) and LAs (1) & Poultry eggs & $\begin{array}{c}\text { ASE: } 2 \mathrm{~g} \text { sample }+4 \mathrm{~g} \text { diatomaceous earth }+0.01 \mathrm{M} \mathrm{KH}_{2} \mathrm{PO}_{4} \text { solution } \\
\text { (a total solvent rinse of } 50 \%) \text {, two cycles }+2 \mathrm{~mL} 0.2 \mathrm{M} \text { sodium dodecyl } \\
\text { sulphonate (SDS) solution + Oasis PRiME HLB } 60 \mathrm{mg} \text {, elution } \\
6 \mathrm{~mL} \mathrm{MeOH}\end{array}$ & [12] \\
\hline MACs (17) and other contaminants (1) & Swine and bovine tissues (muscle, kidney and liver) & $\begin{array}{c}\text { ASE: } 2 \text { g sample }+12 \text { g EDTA-treated sand }+\mathrm{ACN}: \mathrm{MeOH}(1: 1, v / v) \\
\text { (a total solvent rinse of } 60 \%) \text {, two cycles }+5 \mathrm{~mL} \mathrm{MeOH}\end{array}$ & [71] \\
\hline TCs (7) & Porcine, chicken and bovine (muscle and liver) & $\begin{array}{c}\text { ASE: } 2 \mathrm{~g} \text { sample }+5 \mathrm{~g} \text { EDTA-treated sand }+\mathrm{ACN} \text { and } 1 \mathrm{mM} \text { TCA }(\mathrm{pH} \\
4.0)(\text { a total solvent rinse of } 50 \%) \text {, two cycles }\end{array}$ & [72] \\
\hline
\end{tabular}


Table 3. Cont.

Class of Veterinary Drugs

APs (4)

Poultry eggs

\section{Sample Preparation Method}

ASE: $5 \mathrm{~g}$ sample $+4 \mathrm{~g}$ diatomaceous earth +

$\mathrm{MeOH}: \mathrm{NH}_{3} \cdot \mathrm{H}_{2} \mathrm{O}$ :ultrapure water $(97: 2: 1, v / v$ ) (a total solvent rinse of $40 \%$ ), one cycle $+1 \mathrm{~mL} \mathrm{ACN}+10 \mathrm{~mL}$ hexane saturated with $\mathrm{ACN}+5 \mathrm{~mL}$ ACN:water $(4: 6, v / v)$

PCNs (2), APs (1), MACs (2), SAs (4) and other
contaminants (5)

MACs (7), Qs (18), TCs (4), LAs (2), SAs (19) and other contaminants $(40)$

PCNs (2), APs (4), MACs (6), FQs (9), TCs (4), SAs (16) and other contaminants (9)
Milk

Royal jelly

Flatfish, eel and shrimp

Porcine, bovine and ovine muscle

(18)

Pork

Fish tissue

Fish muscle

Edible muscles, eggs and milk

QuEChERS: $10 \mathrm{~g}$ sample $+100 \mu \mathrm{L}$ acetic acid $+10 \mathrm{~mL} \mathrm{ACN}+4 \mathrm{~g}$ $\mathrm{MgSO}_{4}+50 \mathrm{mg}$ chitosan $+150 \mathrm{mg} \mathrm{MgSO} 4$

QuEChERS: $1 \mathrm{~g}$ sample $+5 \mathrm{~mL}$ mixed solution of $0.1 \mathrm{M}$ citric acid and $0.2 \mathrm{M} \mathrm{Na}_{2} \mathrm{HPO}_{4}(8: 5, v / v, \mathrm{pH} 4)+20 \mathrm{~mL} 5 \%$ acetic acid in $\mathrm{ACN}+2 \mathrm{~g}$ $\mathrm{NaCl}+2 \mathrm{~g} \mathrm{Na}_{2} \mathrm{SO}_{4}+200 \mathrm{mg} \mathrm{NH} \mathrm{N}_{2}$ sorbents

QuEChERS: 2 g sample $+1 \mathrm{~mL} 0.1 \mathrm{M}$ EDTA in $50 \mathrm{mM}$ ammonium acetate buffer solution ( $\mathrm{pH} 4.0)+9 \mathrm{~mL} 2 \mathrm{mM}$ ammonium formate in water: $\operatorname{ACN}(1: 4, v / v)+250 \mathrm{mg}$ PSA + $250 \mathrm{mg}$ C18 sorbents

QuEChERS: $4 \mathrm{~g}$ sample $+16 \mathrm{~mL} 5 \%$ acetic acid in $\mathrm{ACN}+2 \mathrm{~g} \mathrm{NaCl}+$ $4 \mathrm{~g} \mathrm{Na}_{2} \mathrm{SO}_{4}+400 \mathrm{mg} \mathrm{C} 18$ sorbents

MSPD: 0.2 g sample + $0.15 \mathrm{~g}$ MMIP + $50 \mathrm{mg} \mathrm{MMIP}+1 \mathrm{~mL} \mathrm{MeOH} \mathrm{+}$

$1 \mathrm{~mL}$ water $+3 \mathrm{~mL} \mathrm{MeOH}:$ water $(2: 8, v / v)+4 \mathrm{~mL} \mathrm{MeOH}$ :acetic acid

$$
(9: 1, \mathrm{v} / \mathrm{v})
$$

MSPD: 0.01 g sample + 0.02 g HLB + $2 \mathrm{~mL} \mathrm{ACN} \mathrm{+} 0.2 \mathrm{~mL} \mathrm{MeOH}$ :water: $\mathrm{NH}_{3} \cdot \mathrm{H}_{2} \mathrm{O}(50: 49: 1, v / v / v)$

Milk

SAs $(14)$

TCs (3)

$\operatorname{APs}(3)$

APs (4), MACs (18), Qs (21), TCs (7), LAs (3), SAs (24) and other contaminants (43)

Eggs

$$
\text { COCs (9) }
$$

Honey

MSPD: milk sample:sorbents $(1: 4, \mathrm{~m} / \mathrm{m})+6 \mathrm{~mL}$ hexane $+6 \mathrm{~mL} 0.1 \mathrm{M}$ citric acid aqueous solution: $\mathrm{MeOH}(1: 9, v / v)$

MSPD: $2 \mathrm{~g}$ sample $+3 \mathrm{~g}$ C18 sorbents $+8 \mathrm{~mL}$ hexane $+10 \mathrm{~mL}$ ACN:water $(1: 1, v / v)+6 \mathrm{~mL}$ ethyl acetate

UAE: 2 g sample + $10 \mathrm{~mL}$ ACN:water $(9: 1, v / v)+10$ min UAE $+5 \mathrm{~mL}$ water + Oasis HLB $500 \mathrm{mg}$, elution $5 \mathrm{~mL}$ formic acid:MeOH $(5: 95, v / v)$ and $5 \mathrm{~mL}$ ethyl acetate

\begin{tabular}{|c|c|c|c|}
\hline COCs (9) & Eggs & $\begin{array}{c}\text { GPC: } 2 \mathrm{~g} \text { sample }+5 \mathrm{~g} \text { anhydrous sodium sulfate }+10 \mathrm{~mL} \text { ethyl acetate } \\
+ \text { online gel permeation chromatographic cleanup }\end{array}$ & [92] \\
\hline $\begin{array}{c}\text { PCNs (8), MACs (5), AGs (1), Qs (7), TCs (4), SAs (6) } \\
\text { and other contaminants (9) }\end{array}$ & Honey & $\begin{array}{l}\text { TFC: } 1 \mathrm{~g} \text { sample }+1 \mathrm{~mL} 0.1 \mathrm{M} \mathrm{Na}_{2} \text { EDTA }(\mathrm{pH} 4)+\text { Millex-GN nylon } \\
\text { filter }(0.20 \mu \mathrm{m})+\text { online sample extraction by TFC procedure }\end{array}$ & [93] \\
\hline
\end{tabular}


Table 3. Cont

Class of Veterinary Drugs

APs (3)

TCs (2)

Shrimp

TCs (4) and Qs (5)

Lamb and chicken tissues, fish, honey, and milk

\section{Sample Preparation Method}

Ref.

FPSE: FPSE media in $1 \mathrm{~mL}$ Cameo $(1: 1, v / v)+0.5 \mathrm{~g}$ sample, kept for

$30 \mathrm{~min}+$ remove the FPSE media from the extraction via and insert it into backextraction containing $0.5 \mathrm{~mL} \mathrm{MeOH}$ for $10 \mathrm{~min}$

SPME: $5 \mathrm{~mL}$ or $5 \mathrm{~g}$ sample $+20 \mathrm{~mL} \mathrm{Na} \mathrm{N}_{2}$ EDTA-McIlvaine extract buffer + a homemade SPME device, elution $2 \mathrm{~mL}$ ACN:formic acid (2:1, v/v)

SLE: 0.5 g sample $+3 \mathrm{~mL} \mathrm{MeOH:ACN}(50: 50 v / v)+0.5 \mathrm{~mL}$

$\mathrm{MeOH}: 0.1 \%$ acetic acid aqueous solution $(40: 60 \mathrm{v} / \mathrm{v})+$ the supernatant was transferred to the falcon tube $+0.5 \mathrm{~mL} \mathrm{MeOH}: 0.1 \%$ acetic acid

$$
\text { aqueous solution }(40: 60 \mathrm{v} / \mathrm{v})
$$

LPME: $5 \mathrm{~g}$ lamb and chicken tissues and fish samples + $15 \mathrm{~mL} \mathrm{ACN} \mathrm{+}$

$5 \mathrm{~g}$ sodium sulfate +19 aqueous solution $\mathrm{mL}(\mathrm{pH}$ 12.0) $5 \mathrm{~g}$ honey

sample $+5 \mathrm{~mL} 2 \mathrm{~mol} / \mathrm{L} \mathrm{HCl}+10 \mathrm{~mL} \mathrm{NaOH}$ solution $(2 \mathrm{~mol} / \mathrm{L}) 20 \mathrm{~mL}$ milk sample $+10 \mathrm{~mL} 0.5 \mathrm{~mol} / \mathrm{L} \mathrm{K}_{3}\left[\mathrm{Fe}(\mathrm{CN})_{6}\right] \cdot 3 \mathrm{H}_{2} \mathrm{O}$ solution $+10 \mathrm{~mL}$

DLLME: $1 \mathrm{~g}$ sample $+6 \mathrm{~mL}$ water:ACN $(5: 1, v / v)+300 \mathrm{mg}$ magnesium sulfate anhydrous $+150 \mathrm{mg}$ sodium chloride $+50 \mathrm{mg}$ trisodium citrate dehydrate + sodium hydroxide solution and formic acid, adjust to $\mathrm{pH}$ $7+1 \mathrm{~mL}$ methanol $+200 \mu \mathrm{L}$ dichloromethane $+100 \mu \mathrm{L}$ water $2 \mathrm{~mol} / \mathrm{L} \mathrm{Zn}\left(\mathrm{CH}_{3} \mathrm{COO}\right)_{2} \cdot 2 \mathrm{H}_{2} \mathrm{O}$ 


\section{Analytical Methods for Detection}

After the sample preparation step, the next step is to detect these analytes in animalderived foods through the use of instruments. In the past decade, many techniques were developed for the detection of veterinary drug residues in animal-derived food samples. Due to the wide variety of veterinary drugs, traditional thin-layer chromatography, LC and GC analysis methods combined with different types of detectors are used to detect and analyse veterinary drugs in animal-derived foods. In addition, traditional analytical methods, including ELISA, CE and micellar electrokinetic capillary chromatography (MEKC), and advanced devices, including electrochemical biosensors, piezoelectric biosensors, optical biosensors, and MIP biosensors, are used to analyse veterinary drugs in animal-derived foods.

\subsection{Liquid Chromatography (LC)}

LC is a common, efficient, and rapid chromatographic method to detect veterinary drugs in animal-derived foods. The key to LC separation is to select a suitable chromatographic column and optimize the composition of the mobile phase and the elution procedure. The LC method has wide applicability and can be used for most veterinary drugs. Generally, analyses of veterinary drugs are conducted by LC coupled with specific detectors, such as fluorescence detectors (FLDs), diode array detectors (DADs), ultraviolet detectors (UVDs) and evaporative light scattering detectors (ELSDs). To date, many methods based on LC combined with various detectors to detect veterinary drugs in animalderived foods have been reported, including LC-FLD [99,100], LC-DAD [94,96,97,101,102], LC-UVD [103-110] and LC-ELSD [111]. At present, the pairing of LC with mass spectrometer detectors (MS and tandem MS) has been widely used in the analysis of veterinary drugs in animal-derived foods [112-114].

Different types of detectors combined with LC are used to detect the same type or different types of veterinary drugs and have their own advantages and disadvantages [11,99]. FLDs are highly sensitive and selective detectors that can detect only compounds that produce fluorescence. DADs and UVDs are mainly used to detect veterinary drugs containing ultraviolet absorbing groups, and they have the advantages of high sensitivity, low noise and wide linear range. ELSDs can detect any sample with lower volatility than the mobile phase. Due to this limitation, it has rarely been used in the detection of veterinary drug residues in animal-derived foods in the past decade. Compared with FLDs, DADs, UVDs and ELSDs, MS detectors can simultaneously detect more than 100 veterinary drugs in animal-derived foods. In addition, MS detectors have high recovery, high selectivity, good reproducibility, and low interference. Moreover, the use of tandem MS improves sensitivity and plays an important role in confirming false positives $[115,116]$. The rapid development of MS detectors, such as triple quadrupole-MS, TOF-MS, QTOF-MS and Orbitrap-HRMS instruments, has greatly improved the efficiency of detecting veterinary drugs in animal-derived foods. The LC-MS/MS method is commonly used to detect veterinary drug residues in animal-derived foods.

\subsection{Gas Chromatography (GC)}

GC is a commonly used chromatographic technique that mainly uses differences in the boiling point, polarity, and adsorption properties of compounds to separate mixtures. For the analysis of veterinary drug residues in animal-derived foods, GC instruments are usually connected to classic detectors, mainly including nitrogen-phosphorus detectors (NPDs), electron capture detectors (ECDs) and MS detectors [117,118]. To date, GC-MS and GC-MS/MS methods are the most commonly used methods to detect veterinary drugs in animal-derived foods. Compared with NPDs and ECDs, MS or MS/MS has good recovery, precision, and reproducibility and can confirm false positives. Generally, derivatization reactions are required for the detection of veterinary drugs by GC $[12,119]$. GC usually requires the selection of specific capillary columns to separate the veterinary drugs in the sample, while optimization of the mobile phase, as in the LC method, is not required. 
GC instruments are relatively expensive, and researchers usually need professional training to operate the instruments. GC is widely used for analysis of pesticides, and GC-MS/MS methods are being gradually developed for research on veterinary drugs. The main reason is that mass spectrum information for some veterinary drugs in the GC mass spectrum library is lacking. Table 4 summarizes some published LC and GC methods for the detection of veterinary drugs in animal-derived foods. 
Table 4. Overview of published LC and GC methods for the analysis of veterinary drugs in animal-derived foods.

\begin{tabular}{|c|c|c|c|c|c|c|c|c|}
\hline Class of Veterinary Drugs & Animal-Derived Food & $\begin{array}{c}\text { Sample Preparation } \\
\text { Method }\end{array}$ & $\begin{array}{l}\text { Detection } \\
\text { Method }\end{array}$ & Recovery (\%) & RSD (\%) & $\begin{array}{c}\text { LOD } \\
(\mu \mathrm{g} / \mathrm{kg} \text { or } \mu \mathrm{g} / \mathrm{L})\end{array}$ & $\begin{array}{c}\text { LOQ } \\
(\mu \mathrm{g} / \mathrm{kg} \text { or } \mu \mathrm{g} / \mathrm{L})\end{array}$ & Ref. \\
\hline SAs (7) & Cattle meats & LLE & HPLC-FLD & $44.6-81.0$ & $2.7-4.9$ & $8-15$ & $13-25$ & [99] \\
\hline APs (3) & Poultry eggs & ASE & UPLC-FLD & $80.1-98.6$ & $1.2-4.3$ & $1.8-4.9$ & $4.3-11.7$ & {$[100]$} \\
\hline APs (3) & Milk & FPSE & HPLC-DAD & $92.3-106.0$ & $1.0-10.7$ & - & - & {$[94]$} \\
\hline SAs (5) & Shrimp & SLE & HPLC-DAD & $90.2-109.0$ & $1.5-14.4$ & 15 & 50 & [96] \\
\hline TCs (4) and Qs (5) & $\begin{array}{l}\text { Lamb and chicken } \\
\text { tissues, fish, honey, and } \\
\text { milk }\end{array}$ & LPME & HPLC-DAD & $25.5-82.6$ & $3.4-10.7$ & $0.5-20$ & $1.25-50$ & [97] \\
\hline FQs (2), TCs (1) and SAs (2) & Porcine tissues & MSPD & HPLC-DAD & $80.6-99.2$ & $0.3-6.1$ & $2-10$ & $7-34$ & [101] \\
\hline PCNs (6) and APs (3) & $\begin{array}{l}\text { Gilthead seabream } \\
\text { tissues }\end{array}$ & SPE & HPLC-DAD & $95.6-104.0$ & $0.3-6.7$ & 11.0-20.4 & $33.2-61.7$ & [102] \\
\hline $\operatorname{COCs}(2)$ & $\begin{array}{c}\text { Cattle and chicken } \\
\text { muscle }\end{array}$ & SPE & HPLC-UVD & $78.5-107.1$ & $2.2-10.9$ & $40-130$ & $130-420$ & [103] \\
\hline SAs (4) & Chicken muscle & LLE & HPLC-UVD & $70.0-84.0$ & $8.0-13.0$ & $0.14-6.53$ & $0.42-19.6$ & {$[104]$} \\
\hline PCNs (2) & $\begin{array}{l}\text { Eggs, chicken and } \\
\text { bovine tissues }\end{array}$ & LLE & HPLC-UVD & $95.5-102.3$ & $0.4-1.2$ & 500-1300 & $1700-4500$ & [106] \\
\hline TCs (3) & $\begin{array}{l}\text { Eggs, milk and milk } \\
\text { powder }\end{array}$ & SPE & HPLC-UVD & $85.3-98.3$ & $1.9-5.3$ & $0.76-1.13$ & $2.53-3.77$ & [107] \\
\hline TCs (4) & Milk and eggs & SPE & HPLC-UVD & $84.2-98.6$ & $1.4-5.9$ & $1.03-2.67$ & $3.46-8.97$ & [108] \\
\hline SAs (4) & Chicken meat & SPE & HPLC-UVD & $92.0-106.0$ & $3.8-6.7$ & $0.5-150$ & - & [109] \\
\hline SAs (15) & $\begin{array}{l}\text { Milk, pork, beef and } \\
\text { mutton tissues }\end{array}$ & LLE & HPLC-UVD & $81.5-95.3$ & $0.8-7.4$ & $6.5-11.0$ & - & [110] \\
\hline $\begin{array}{l}\text { MACs (7), Qs (18), TCs (4), } \\
\text { LAs (2), SAs (19) and other } \\
\text { contaminants (40) }\end{array}$ & Royal jelly & QuEChERS & $\begin{array}{c}\text { UPLC-QTOF- } \\
\text { MS }\end{array}$ & $70.2-120.1$ & $1.8-9.9$ & $0.06-6.0$ & $0.21-20$ & {$[76]$} \\
\hline PCNs (2), APs (1) and TCs (2) & Milk & QuEChERS & LC-TOF-MS & $83.0-92.0$ & $1.1-8.8$ & $0.0075-1.92$ & $0.025-6.39$ & [78] \\
\hline
\end{tabular}


Table 4. Cont

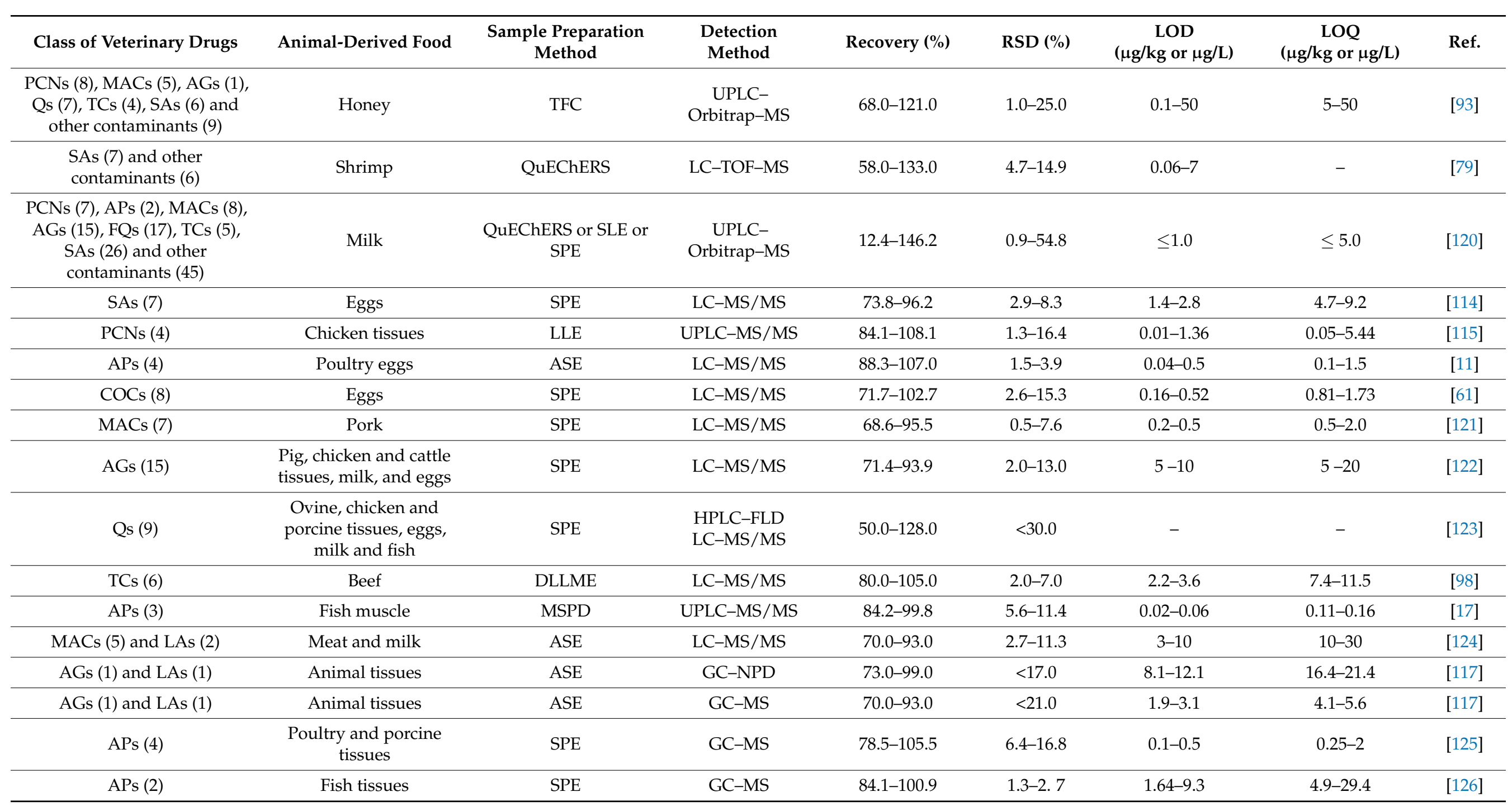


Table 4. Cont.

\begin{tabular}{|c|c|c|c|c|c|c|c|c|}
\hline Class of Veterinary Drugs & Animal-Derived Food & $\begin{array}{c}\text { Sample Preparation } \\
\text { Method }\end{array}$ & $\begin{array}{l}\text { Detection } \\
\text { Method }\end{array}$ & Recovery (\%) & RSD (\%) & $\begin{array}{c}\text { LOD } \\
(\mu \mathrm{g} / \mathrm{kg} \text { or } \mu \mathrm{g} / \mathrm{L})\end{array}$ & $\begin{array}{c}\text { LOQ } \\
(\mu \mathrm{g} / \mathrm{kg} \text { or } \mu \mathrm{g} / \mathrm{L})\end{array}$ & Ref. \\
\hline $\begin{array}{l}\text { APs }(1) \text { and other } \\
\text { contaminants }(8)\end{array}$ & Fish & QuEChERS-GPC & GC-MS & $63.5-90.2$ & $3.6-15.4$ & $0.3-1.0$ & - & [127] \\
\hline AGs (1) and LAs (1) & Poultry eggs & ASE-SPE & GC-MS/MS & $80.0-95.7$ & $1.0-3.4$ & $2.3-4.3$ & $5.6-9.5$ & [12] \\
\hline COCs (1) & Chicken and pig tissues & ASE-SPE & GC-MS/MS & $77.5-96.3$ & $1.6-6.6$ & $1.4-1.6$ & $4.8-5.2$ & [119] \\
\hline COCs (2) & Chicken tissues & ASE-SPE & GC-MS/MS & $82.0-94.3$ & $1.7-5.4$ & $0.8-2.5$ & $2.7-8.0$ & [128] \\
\hline
\end{tabular}

Note: " - " indicates not reported. 


\subsection{Enzyme-Linked Immunosorbent Assay (ELISA)}

ELISA is an ultramicro-experimental detection technology with high sensitivity and specificity established by combining modern detection methods with immune technology. ELISA has the advantages of easy operation, convenience, high efficiency, strong specificity, and low detection cost and is widely used in the detection of veterinary drug residues in animal-derived foods [130-139]. Samsidar et al. [20] introduced two forms ELISA: direct competitive (dc)-ELISA and indirect competitive (ic)-ELISA, of which the ic-ELISA method is more advanced. In the past decade, this reliable high-throughput immunoassay has been widely used to determine various veterinary drugs in animal-derived foods. The basic principle of ELISA is to combine a specific antigen-antibody immunological reaction with an enzymatic catalytic reaction and to display the primary immune response with amplification of the enzymatic reaction. This method can detect both antigen and antibody.

Several ELISA methods for the detection of veterinary drugs have been reported. An et al. [130] applied the ic-ELISA method to detect FF and TAP in edible animal tissue and feed. The recovery, precision and LODs of FF and TAP in animal tissues are $80.6-105.5 \%, 3.5-14.1 \%$ and $0.07-0.14 \mu \mathrm{g} / \mathrm{kg}$, respectively. These values show that the ic-ELISA method successfully detected FF and TAP in animal tissues. Zhou et al. [134] reported a novel, convenient and efficient ic-ELISA method to detect 20 SA residues in edible animal tissues. The LODs of SAs in animal tissues were $1.5-22.3 \mu \mathrm{g} / \mathrm{kg}$, and the recoveries were $70.6-121.0 \%$, with less than $24.1 \%$ RSD. A comparative study of ELISA and HPLC-UVD methods was performed by Bahmani et al. [135] for analysis of TCs in a multiresidue sample. For the ELISA method, the recovery of 4 TCs was $71.9-100.0 \%$, with an RSD lower than $10 \%$, and the LODs and LOQs of meat and raw milk samples were 3.7-9 $\mu \mathrm{g} / \mathrm{kg}$ and 9-27 $\mu \mathrm{g} / \mathrm{L}$, respectively. This study also used the HPLC-UVD method to confirm the analysis of TC residues in meat and raw milk samples. The recovery and precision of the ELISA method are lower than those of the HPLC-UVD method, but the sample preparation steps are simple, and the recovery and precision of the ELISA method meet the EU method parameter requirements [140]. The ELISA method simplifies the sample preparation steps, greatly shortens the entire experimental duration, and does not require expensive equipment. Due to its advantages of being inexpensive, selective, and efficient, the ELISA method is still used for the screening of veterinary drug residues in animal-derived foods.

\subsection{Capillary Electrophoresis (CE)}

$\mathrm{CE}$ is a new type of liquid-phase separation technology that uses capillaries as the separation channel and a high-voltage direct current electric field as the driving force. $\mathrm{CE}$ is an efficient, fast, and economical automated separation technology with the advantages of low reagent consumption, small sample injection volume and high separation efficiency. CE has certain limitations in sample preparation ability, sensitivity, and separation reproducibility. The reasons for these limitations are the small injection volume, small capillary diameter, and electroosmotic changes due to sample composition. Due to the low sensitivity caused by the small injection volume, CE has been combined with some high-sensitivity detectors, including UVDs [141-143], laser-induced fluorescence (LIF) detectors [144], electrochemiluminescence (ECL) detectors [145], DADs [146], MS detectors [147,148] and chemiluminescence (CL) detectors [149].

Recently, Yang et al. [150] developed a pressure-assisted electrokinetic injection (PAEKI) method coupled with capillary zone electrophoresis (CZE) for the determination of 6 SAs in different animal husbandry products. Briefly, an on-line PAEKI method for the simultaneous enrichment of six SAs was used to increase the sensitivity of CZE. The LODs and LOQs ranged from 1.8-63.8 $\mu \mathrm{g} / \mathrm{L}$ and 6.1-182.6 $\mu \mathrm{g} / \mathrm{L}$, respectively, in milk, pork and egg samples. Moreno-González et al. [148] reported the use of MIPs as SPE sorbents (MISPE) to extract 9 AGs from honey samples via CZE-MS/MS determination. In this study, the MISPE extraction method and an MS/MS detector were used, which greatly improved the resolution and sensitivity (LODs, $0.4-28.5 \mu \mathrm{g} / \mathrm{kg}$ ). The proposed 
MISPE-CZE-MS/MS method successfully detected 9 AGs in honey samples and obtained good recovery (88.2-99.8\%) and precision (RSDs lower than 8\%). Hu et al. [151] established a novel approach for on-line enzyme assays for penicillinase using CE-integrated immobilized enzyme reactors (IMERs). The CE-IMER method was used to detect penicillin in pork samples, achieving good recovery (96.3-110.8\%) and precision (RSDs, $1.5-3.1 \%$ ). SPE in combination with a large-volume sample stacking (LVSS)-CE system has been described and applied to detect four TCs, providing sensitive, rapid, simple, and efficient on-line preconcentration of TC residues in milk samples [152]. The LODs obtained were $18.60-23.83 \mu \mathrm{g} / \mathrm{L}$ for the four analytes, with inter- and intraday repeatabilities $<10 \%$. To date, the CE method is widely used to detect various veterinary drugs in animal-derived foods [153-157].

\subsection{Micellar Electrokinetic Capillary Chromatography (MEKC)}

MEKC is a novel hybrid method that combines the separation principles of chromatography and electrophoresis. MEKC is an important form of CE and has become one of the most popular technologies for separating veterinary drugs due to its high separation power and ability to separate both ionic and neutral compounds [158]. In MEKC, an ionic surfactant such as sodium dodecyl sulfate (SDS) is added to the buffer to form micelles. The separated substances are distributed between the aqueous phase and the micellar phase and migrate in the capillary with electroosmotic flow, thereby achieving a separation effect [159]. Because of its simple operation, few sample pre-processing steps, and low instrumentation cost, this method was used in the detection of veterinary drug residues in animal-derived foods in recent years.

To date, the use of MEKC has been reported for detecting Q [159], LA [160], COC [161], AP [162], SA [163] and PCN [164] residues in poultry tissues, milk, and eggs. Kowalski et al. [160] established a MEKC method combined with a UVD for the detection of lincomycin and clindamycin in poultry tissue samples. In this study, a mixture of $10 \mathrm{mM}$ sodium tetraborate decahydrate ( $\mathrm{pH}$ 9.3) and $25 \mathrm{mM}$ SDS was used as an ionic surfactant for MEKC. The LODs and LOQs of lincomycin and clindamycin were 13.2 and $18.5 \mu \mathrm{g} / \mathrm{kg}$ and 44.2 and $61.5 \mu \mathrm{g} / \mathrm{kg}$, respectively. The recovery (97.5-109.5\%) and precision (3.9-11.7\%) of the proposed method show the successful application for lincomycin and clindamycin residues in poultry tissues. In addition, Belal et al. [161] developed a MEKC method by using a CE-DAD system for the detection of five COCs in chicken tissues. Under optimized separation conditions, the separation time of these analytes was less than 14 min. MEKC was performed in $50 \mathrm{mM}$ tris buffer ( $\mathrm{pH} 8.5$ ) with $50 \mathrm{mM}$ SDS and $15 \%$ ACN $(v / v)$ at $28 \mathrm{kV}$ and $200 \mathrm{~nm}$. The LODs and LOQs were obtained for five COCs (65-172 and 183-493 $\mu \mathrm{g} / \mathrm{L}$ ), and the recovery and precision were obtained for chicken tissues (97.0-99.4\% and 0.8-1.8\%). Shao et al. [164] applied a novel analytical procedure developed for the simultaneous separation and detection of 6 PCNs in milk and eggs. For the analytical procedure, an on-line preconcentration and clean-up procedure was developed by using LVSS with polarity switching prior to MEKC or HPLC separation. Under the optimized conditions, the enrichment factors of 6 PCNs ranged from 150 to 601, and the LODs ranged from 0.16 to $0.26 \mu \mathrm{g} / \mathrm{kg}$. This study used HPLC-UVD and MEKC methods to analyze the multi-residue content of 6 PCNs in milk and eggs. The HPLC-UVD and MEKC recoveries were all higher than $78.3 \%$ and $79.3 \%$, respectively, and the RSDs were all lower than $4.1 \%$ and $5.2 \%$, respectively. Compared with the HPLC-UVD method, the MEKC method achieves better separation. Some published ELISA, CE and MEKC methods for the detection of veterinary drugs in animal-derived foods are summarized in Table 5. 
Table 5. Overview of published ELISA, CE and MEKC methods for the analysis of veterinary drugs in animal-derived foods.

\begin{tabular}{|c|c|c|c|c|c|c|c|c|c|}
\hline Veterinary Drug & Class & $\begin{array}{c}\text { Animal-Derived } \\
\text { Food }\end{array}$ & $\begin{array}{c}\text { Sample Preparation } \\
\text { Method }\end{array}$ & $\begin{array}{l}\text { Detection } \\
\text { Method }\end{array}$ & Recovery (\%) & RSD (\%) & $\begin{array}{c}\text { LOD } \\
(\mu \mathrm{g} / \mathrm{kg} \text { or } \mu \mathrm{g} / \mathrm{L})\end{array}$ & $\begin{array}{c}\text { LOQ } \\
(\mu \mathrm{g} / \mathrm{kg} \text { or } \mu \mathrm{g} / \mathrm{L})\end{array}$ & Ref. \\
\hline FF and TAP & APs & Animal tissues & LLE & ic-ELISA & $80.6-105.5$ & $3.5-14.1$ & $0.07-0.14$ & - & [130] \\
\hline LIN & LAs & Milk and honey & LLE & ic-ELISA & $84.6-115.6$ & $1.7-25.4$ & 2.1 & - & [131] \\
\hline ERY & MACs & Milk & LLE & ic-ELISA & $76.9-85.7$ & $5.1-11.3$ & 0.3 & - & [132] \\
\hline SAL & COCs & Chicken tissues & LLE & ic-ELISA & $85.7-99.3$ & $1.6-6.6$ & $18-22$ & - & [133] \\
\hline $20 \mathrm{SAs}$ & SAs & Animal tissues & LLE & ic-ELISA & $70.6-121.0$ & $0.8-24.1$ & $1.5-22.3$ & - & [134] \\
\hline 13 FQs and 22 SAs & FQs and SAs & Milk & MSPD & DC-ELISA & $67.0-105.0$ & $4.8-16.4$ & $2.4-5.8$ & - & [136] \\
\hline NEO & AGs & $\begin{array}{l}\text { Animal tissues, } \\
\text { eggs and milk }\end{array}$ & LLE & ELISA & $65.8-122.8$ & $5.9-28.6$ & $5.7-29.3$ & $11.4-59.7$ & [137] \\
\hline 6 PCNs and 4 TCs & PCNs and TCs & Milk & LLE & ic-ELISA & $80.8-99.4$ & $3.0-12.7$ & $0.4-3.7$ & - & [138] \\
\hline KAN and STR & AGs & Milk & LLE & dot-ELISA & $84.2-124.5$ & $4.5-12.4$ & $0.09-1.37$ & $0.38-38.66$ & [139] \\
\hline SDZ, SMR and SMZ & SAs & Milk & SPME & CE-LIF & $91.1-94.6$ & $0.9-1.1$ & $0.25-0.47$ & $0.78-1.54$ & [144] \\
\hline $\begin{array}{l}\text { AZI, TIL, ACE and } \\
\text { ROX }\end{array}$ & MACs & Egg & LLE & CE-ECL & $89.3-107.5$ & $1.3-5.6$ & $1.3-70 \mathrm{nmol} / \mathrm{L}$ & 93-2100 nmol/L & [145] \\
\hline $7 \mathrm{Qs}$ & Qs & Milk & MSPE & CE-DAD & $74.0-98.0$ & $1.0-9.9$ & $9-12$ & - & [146] \\
\hline $8 \mathrm{Qs}$ & Qs & Milk & MISPE & CE-MS/MS & $70.0-102.3$ & $3.0-12.0$ & $1.0-1.4$ & $3.2-4.7$ & [147] \\
\hline 9 AGs & AGs & Honey & MISPE & CE-MS/MS & $88.2-99.8$ & $2.4-6.8$ & $0.4-28.5$ & $1.4-94.8$ & [148] \\
\hline $\mathrm{SDD}, \mathrm{SDZ}$ and STZ & SAs & $\begin{array}{l}\text { Milk, pork and } \\
\text { chicken meat }\end{array}$ & SPE & CE-CL & $79.5-112.4$ & $2.1-2.8$ & $0.65-3.14$ & - & [149] \\
\hline $6 \mathrm{SAs}$ & SAs & Milk, pork and egg & LLE & PAEKI-CZE & $89.0-113.0$ & $1.6-8.4$ & $1.8-63.8$ & $6.1-182.6$ & [150] \\
\hline $\mathrm{PCN}$ & PCNs & Pork & LLE & CE-IMERs & $96.3-110.8$ & $1.5-3.1$ & - & - & [151] \\
\hline CT, DT, OT and TC & TCs & Milk & SPE & LVSS-CE & - & $1.7-9.7$ & $18.6-23.83$ & - & [152] \\
\hline 4 Qs and 3 SAs & Qs and SAs & Aquatic product & ASE & LVSS-CE & $84.3-95.7$ & $1.1-4.7$ & $13-35$ & $40-100$ & [153] \\
\hline
\end{tabular}


Table 5. Cont.

\begin{tabular}{|c|c|c|c|c|c|c|c|c|c|}
\hline Veterinary Drug & Class & $\begin{array}{l}\text { Animal-Derived } \\
\text { Food }\end{array}$ & $\begin{array}{c}\text { Sample Preparation } \\
\text { Method }\end{array}$ & $\begin{array}{l}\text { Detection } \\
\text { Method }\end{array}$ & Recovery (\%) & RSD (\%) & $\begin{array}{c}\text { LOD } \\
(\mu \mathrm{g} / \mathrm{kg} \text { or } \mu \mathrm{g} / \mathrm{L})\end{array}$ & $\begin{array}{c}\text { LOQ } \\
(\mu \mathrm{g} / \mathrm{kg} \text { or } \mu \mathrm{g} / \mathrm{L})\end{array}$ & Ref. \\
\hline OT & TCs & Milk & SPME & CE-DAD & 89.9 & 2.25 & 70 & - & [154] \\
\hline PCN G and PCN acid & PCNs & Milk & LLE & CZE & $89.2-96.8$ & $3.1-7.3$ & $10-500$ & $40-1700$ & [155] \\
\hline 8 TCs and 7 Qs & TCs and Qs & Milk & LLE & CZE-QTOF-MS & $72.6-105.8$ & $2.1-10.5$ & $0.5-2.9$ & $1.6-9.7$ & [156] \\
\hline TIL and TYL & MACs & Chicken fat & RUSAEME & CE-DAD & 73.0-117.0 & $0.7-12.4$ & $5.2-18.9$ & $17.4-55.0$ & [157] \\
\hline LIN and CLI & LAs & Poultry tissues & SPE & MEKC-UVD & $97.5-109.5$ & $3.9-11.7$ & $13.2-18.5$ & $44.2-61.5$ & [160] \\
\hline $5 \mathrm{COCs}$ & COCs & Chicken Tissues & LLE & MEKC-DAD & 97.0-99.4 & $0.8-1.8$ & $65-172$ & $183-493$ & [161] \\
\hline $\begin{array}{c}\text { CIP, ENR, CAP and } \\
\text { FF }\end{array}$ & FQs and APs & Milk & SPE & MEKC-DAD & $80.0-109.0$ & $0.1-4.8$ & $6.8-13.9$ & - & [162] \\
\hline 7 SAs and 3 APs & SAs and APs & Poultry tissues & SPE & MEKC-UVD & $86.4-109.4$ & $3.1-14.9$ & $1.3-7.8$ & $4.5-26.1$ & [163] \\
\hline 6 PCNs & PCNs & Milk and egg & LLE & $\begin{array}{l}\text { LVSS-MEKC- } \\
\text { UVD }\end{array}$ & 79.3-103.6 & $2.0-5.2$ & $0.16-0.26$ & 2 & [164] \\
\hline
\end{tabular}

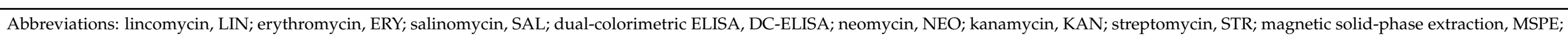

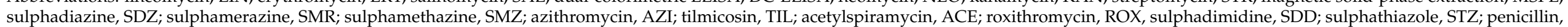

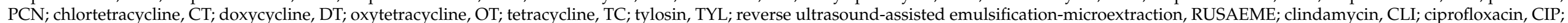
enrofloxacin. ENR. Note: "-" indicates not reported. 


\section{Advanced Methods for Detection}

With the continuous development of detection technology, advanced sensor-led detection technology has emerged, providing a fast, efficient, and cost-effective method for detecting veterinary drug residues in animal-derived foods. Traditional chromatographic techniques are used in combination with different detectors to provide sensitivity, specificity, and reliability for analysis, but the disadvantages are that they consume large amounts of organic reagents, are time consuming and expensive and are not suitable for a large number of screening samples. Advanced methods are used as alternative detection methods to detect veterinary drug residues in animal-derived foods, including methods involving electrochemical biosensors [21,165], piezoelectric biosensors [166], optical biosensors [167-169], and MIP biosensors [170,171]. The developed sensor analysis method not only has the advantages of simple operation, high speed and low cost but also provides satisfactory results in terms of specificity, sensitivity, and recovery in the detection of veterinary drugs in animal-derived foods.

To date, electrochemical biosensors have been used to detect CAP, TC, AMP and PCN in milk, honey, chicken, and beef [172-176]. Wang et al. [172] developed a green and efficient synthesis approach for chlorine-doped reduced graphene oxide (Cl-RGO) and constructed a highly selective electrochemical sensor for CAP based on Cl-RGO. The sensor has excellent reproducibility (102.4-103.5\%) and storage stability and has been successfully used for CAP detection in milk samples. The application of MWCNTs and electropolymerized poly (L-glutamic acid) in electrochemical aptasensors has been used for the detection of TC in honey samples [173]. The developed method detected TC based on the direct electrodeposition of a polyglutamic acid (PGA)-MWCNT-glassy carbon electrode (GCE). The LOD obtained was as low as $3.7 \times 10^{-11} \mathrm{mM}$ for TC. This method uses one-step modification of the electrode surface, which decreases the time consumption of the modification process and provides good sensitivity. The research reported by Li et al. [176] is based on the manufacture of electrochemical biosensors with hybrid nanowire/nanoparticle arrays with various biomolecular receptors for simultaneous detection of PCN and TC in chicken and beef. This established method has obtained good recovery, precision (3.4-4.5\%) and sensitivity (LOD, 10.5-15.2 $\mu \mathrm{M}$ ) and has been successfully applied to the detection of PCN and TC in chicken and beef. Some published advanced methods, including methods that use electrochemical biosensors, piezoelectric biosensors, optical biosensors, MIP biosensors and other biosensors for the detection of veterinary drugs in animal-derived foods, are summarized in Table 6. Biosensors exhibit low reagent consumption and high sensitivity and save time and labor, and their application in the detection of veterinary drugs in animal-derived foods will become a trend.

Table 6. Overview of published advanced methods for the analysis of veterinary drugs in animal-derived foods.

\begin{tabular}{|c|c|c|c|c|c|c|}
\hline Veterinary Drug & Class & $\begin{array}{c}\text { Animal-Derived } \\
\text { Food }\end{array}$ & $\begin{array}{l}\text { Detection } \\
\text { Method }\end{array}$ & Recovery (\%) & $\begin{array}{c}\text { LOD } \\
(\mu \mathrm{M} \text { or } \mu \mathrm{g} / \mathrm{L})\end{array}$ & Ref. \\
\hline CAP & APs & Milk & $\begin{array}{c}\text { Electrochemical } \\
\text { sensor }\end{array}$ & $102.4-103.5$ & 1 & [172] \\
\hline $\mathrm{TC}$ & TCs & Honey & $\begin{array}{l}\text { Electrochemical } \\
\text { aptasensor }\end{array}$ & $94.0-95.0$ & $3.7 \times 10^{-11}$ & [173] \\
\hline AMP & PCNs & Milk & $\begin{array}{l}\text { Electrochemical } \\
\text { biosensor }\end{array}$ & $95.0-98.1$ & $1.0 \times 10^{-3}$ & [174] \\
\hline PCN & PCNs & Milk & $\begin{array}{l}\text { Electrochemical } \\
\text { aptasensor }\end{array}$ & $96.0-105.4$ & 0.057 & [175] \\
\hline PCN and TC & PCNs and TCs & Chicken and beef & $\begin{array}{l}\text { Electrochemical } \\
\text { biosensor }\end{array}$ & - & $10.5-15.2$ & [176] \\
\hline
\end{tabular}


Table 6. Cont.

\begin{tabular}{|c|c|c|c|c|c|c|}
\hline Veterinary Drug & Class & $\begin{array}{c}\text { Animal-Derived } \\
\text { Food }\end{array}$ & $\begin{array}{l}\text { Detection } \\
\text { Method }\end{array}$ & Recovery (\%) & $\begin{array}{c}\text { LOD } \\
(\mu \mathrm{M} \text { or } \mu \mathrm{g} / \mathrm{L})\end{array}$ & Ref. \\
\hline STZ & SAs & Honey & $\begin{array}{l}\text { Piezoelectric } \\
\text { immunosensor }\end{array}$ & 100.0-113.0 & $0.1 \mu \mathrm{g} / \mathrm{kg}$ & [166] \\
\hline $\begin{array}{l}\text { CAP, SDZ and } \\
\text { NEO }\end{array}$ & $\begin{array}{c}\text { APs, SAs and } \\
\text { AGs }\end{array}$ & Milk & $\begin{array}{l}\text { Optical } \\
\text { fiber-mediated } \\
\text { immunosensor }\end{array}$ & $85.0-109.4$ & $0.00286-30$ & [177] \\
\hline CAP & APs & $\begin{array}{l}\text { Porcine muscle, } \\
\text { honey, milk and } \\
\text { prawn }\end{array}$ & MIP biosensor & $87.0-103.0$ & $7 \times 10^{-5}$ & [178] \\
\hline CAP & APs & Milk & MIP biosensor & $96.0-105.0$ & $3 \times 10^{-7}$ & [179] \\
\hline NEO and KAN & AGs & Dairy products & $\begin{array}{l}\text { Ellipsometric } \\
\text { sensor }\end{array}$ & $96.8-106.3$ & $0.048-0.22$ & [180] \\
\hline PCN & PCNs & Milk & $\begin{array}{c}\text { Single layer and } \\
\text { bilayer } \\
\text { potentiometric } \\
\text { biosensors }\end{array}$ & $102.0-124.0$ & 0.3 & [181] \\
\hline
\end{tabular}

Note: "-" indicates not reported.

\section{Conclusions}

Veterinary drug residues in animal-derived foods are an issue that warrants attention and are related to human health and safety. Different sample preparation techniques are suitable for different animal food matrices, each with its own advantages and disadvantages. However, compared with other sample preparation techniques, the ASE method has the advantages of full automation, low reagent consumption and batch processing of samples, so this method is worth promoting. Compared with LC and GC instruments, ELISA, CE and MEKC methods require relatively inexpensive testing equipment. For laboratories without LC and GC equipment, these three methods can be selected to screen and analyse veterinary drug residues. The LC-MS/MS method can be used to quantitatively and qualitatively analyse veterinary drug residues in animal-derived foods. This method has a wide range of applicability and does not require derivatization reactions, making it worthy of recommendation as a detection method. Considering the cost and time savings, advanced methods have been developed as alternative methods. Compared with analytical techniques, enzyme biosensors can provide better sensitivity and precision in the detection of veterinary drug residues in animal-derived foods and can detect lower concentrations. At present, biosensors that can detect veterinary drugs in animal-derived food are still limited, requiring researchers to continue to develop low cost, environmentally optimized biosensors.

Author Contributions: Conceptualization, B.W., K.X. and K.L.; Data Curation, B.W.; Formal Analysis, B.W. and K.X.; Funding Acquisition, B.W., K.X. and K.L.; Investigation, B.W.; Methodology, B.W.; Resources, B.W., K.X. and K.L.; Writing of Original Draft, B.W.; and Writing of Review \& Editing, B.W. All authors have read and agreed to the published version of the manuscript.

Funding: This research was financially supported by the Yangzhou University International Academic Exchange Foundation, the Yangzhou University Excellent Doctoral Dissertation Foundation, Postgraduate Research \& Practice Innovation Program of Jiangsu Province (SJCX20_1360), the China Agriculture Research System (CARS-41-G23), the Priority Academic Program Development of Jiangsu Higher Education Institutions (PAPD), the Yangzhou University High-End Talent Support Program, and a National Research Foundation (NRF) grant (No. 2019R1A6A1A03031807) funded by the Ministry of Education of Korea.

Institutional Review Board Statement: Not applicable.

Informed Consent Statement: Not applicable. 
Data Availability Statement: Data supporting reported results can be obtained from any masthead.

Conflicts of Interest: The authors declare no conflict of interest.

\section{References}

1. Tufa, T.B. Veterinary drug residues in food-animal products: Its risk factors and potential effects on public health. J. Vet. Sci. Technol. 2015, 7, 1-7. [CrossRef]

2. Gehring, R.; Baynes, R.E.; Riviere, J.E. Application of risk assessment and management principles to the extralabel use of drugs in food-producing animals. J. Vet. Pharmacol. Ther. 2006, 29, 5-14. [CrossRef]

3. Boobis, A.; Cerniglia, C.; Chicoine, A.; Fattori, V.; Lipp, M.; Reuss, R.; Verger, P.; Tritscher, A. Characterizing chronic and acute health risks of residues of veterinary drugs in food: Latest methodological developments by the joint FAO/WHO expert committee on food additives. Crit. Rev. Toxicol. 2017, 47, 885-899. [CrossRef]

4. Bartikova, H.; Skálová, L.; Stuchlíková, L.; Vokřál, I.; Vanek, T.; Podlipná, R. Xenobiotic-metabolizing enzymes in plants and their role in uptake and biotransformation of veterinary drugs in the environment. Drug Metab. Rev. 2015, 47, 374-387. [CrossRef]

5. The European Medicines Agency. Commission Regulation (EU) No. 37/2010 of 22 December 2009 on Pharmacologically Active Substances and their Classification Regarding Maximum Residue Limits in Foodstuffs of Animal Origin; The European Medicines Agency: Amsterdam, The Netherlands, 2010.

6. US Food and Drug Administration. CFR-Code of Federal Regulations Title 21 Part 556 Tolerances for Residue of New Animal Drugs in Food; US Food and Drug Administration: Rockville, MD, USA, 2014.

7. Ministry of Agriculture of the People's Republic of China. Maxium Residue Level of Veterinary Drugs in Food of Animal Origin; Notice No. 235 (Appendix 4); Ministry of Agriculture of the People's Republic of China: Beijing, China, 2002.

8. Kirchhelle, C. Pharming animals: A global history of antibiotics in food production (1935-2017). Palgrave Commun. 2018, 4, 96. [CrossRef]

9. Li, R.; Lin, Z.J.; Yang, J.Y.; Xu, Z.L.; Wang, H.; Lei, H.T.; Sun, Y.M.; Shen, Y.D. An indirect competitive enzyme-linked immunosorbent assay for simultaneous determination of florfenicol and thiamphenicol in animal meat and urine. Chin. J. Anal. Chem. 2018, 46, 1321-1328. [CrossRef]

10. Kowalski, P.; Oledzka, I.; Lamparczyk, H. Capillary electrophoresis in analysis of veterinary drugs. J. Pharm. Biomed. Anal. 2003, 32, 937-947. [CrossRef]

11. Wang, B.; Zhao, X.; Xie, X.; Xie, K.; Zhang, G.; Zhang, T.; Liu, X. Development of an accelerated solvent extraction approach for quantitative analysis of chloramphenicol, thiamphenicol, florfenicol, and florfenicol amine in poultry eggs. Food Anal. Methods 2019, 12, 1705-1714. [CrossRef]

12. Wang, B.; Wang, Y.; Xie, X.; Diao, Z.; Xie, K.; Zhang, G.; Zhang, T.; Dai, G. Quantitative analysis of spectinomycin and lincomycin in poultry eggs by accelerated solvent extraction coupled with gas chromatography tandem mass spectrometry. Foods $2020,9,651$. [CrossRef] [PubMed]

13. Jank, L.; Martins, M.T.; Arsand, J.B.; Motta, T.M.C.; Hoff, R.B.; Barreto, F.; Pizzolato, T.M. High-throughput method for macrolides and lincosamides antibiotics residues analysis in milk and muscle using a simple liquid-liquid extraction technique and liquid chromatography-electrospray-tandem mass spectrometry analysis (LC-MS/MS). Talanta 2015, 144, 686-695. [CrossRef]

14. Płotka-Wasylka, J.; Szczepańska, N.; De La Guardia, M.; Namieśnik, J. Miniaturized solid-phase extraction techniques. TrAC Trends Anal. Chem. 2015, 73, 19-38. [CrossRef]

15. Richter, B.E.; Raynie, D. Accelerated solvent extraction (ASE) and high-temperature water extraction. Compr. Sampl. Sample Prep. 2012, 2, 105-115. [CrossRef]

16. Liu, H.Y.; Lin, S.L.; Fuh, M.R. Determination of chloramphenicol, thiamphenicol and florfenicol in milk and honey using modified QuEChERS extraction coupled with polymeric monolith-based capillary liquid chromatography tandem mass spectrometry. Talanta 2016, 150, 233-239. [CrossRef] [PubMed]

17. Pan, X.D.; Wu, P.G.; Jiang, W.; Ma, B.J. Determination of chloramphenicol, thiamphenicol, and florfenicol in fish muscle by matrix solid-phase dispersion extraction (MSPD) and ultra-high pressure liquid chromatography tandem mass spectrometry. Food Control. 2015, 52, 34-38. [CrossRef]

18. Chen, D.; Yu, J.; Tao, Y.; Pan, Y.; Xie, S.; Huang, L.; Peng, D.; Wang, X.; Wang, Y.; Liu, Z.; et al. Qualitative screening of veterinary anti-microbial agents in tissues, milk, and eggs of food-producing animals using liquid chromatography coupled with tandem mass spectrometry. J. Chromatogr. B Anal. Technol. Biomed. Life Sci. 2016, 1017-1018, 82-88. [CrossRef]

19. Yang, F.; Zhang, W.; Gu, C.; Xu, J.; Zhou, K. Separation of seven residues of fluoroquinolones from fish samples using solid phase microextraction and Electrophoresis and their detection by Electrochemiluminescence method. Int. J. Electrochem. Sci. 2020, 15, 9300-9312. [CrossRef]

20. Samsidar, A.; Siddiquee, S.; Shaarani, S.M. A review of extraction, analytical and advanced methods for determination of pesticides in environment and foodstuffs. Trends Food Sci. Technol. 2018, 71, 188-201. [CrossRef]

21. Majdinasab, M.; Yaqub, M.; Rahim, A.; Catanante, G.; Hayat, A.; Marty, J.L. An overview on recent progress in electrochemical biosensors for antimicrobial drug residues in animal-derived food. Sensors 2017, 17, 1947. [CrossRef]

22. JECFA. Residue Evaluation of Certain Veterinary Drugs (Seventy-Fifth Report of the Joint FAO/WHO Expert Committee on Food Additives); FAO JECFA Monographs 12; Food and Agriculture Organization of the United Nations: Rome, Italy, 2012.

23. Blumenthal, K.G.; Peter, J.G.; Trubiano, J.A.; Phillips, E.J. Antibiotic allergy. Lancet 2019, 393, 183-198. [CrossRef] 
24. Graziani, C.; Busani, L.; Dionisi, A.M.; Lucarelli, C.; Owczarek, S.; Ricci, A.; Mancin, M.; Caprioli, A.; Luzzi, I. Antimicrobial resistance in Salmonella enterica serovar Typhimurium from human and animal sources in Italy. Vet. Microbiol. 2008, 128, 414-418. [CrossRef] [PubMed]

25. Hanekamp, J.C.; Bast, A. Antibiotics exposure and health risks: Chloramphenicol. Environ. Toxicol. Pharmacol. 2015, 39, 213-220. [CrossRef]

26. Kaiser, G. Protein Synthesis Inhibitors: Macrolides Mechanism of Action Animation. In Classification of Agents Pharmamotion; The Community College of Baltimore County: Baltimore County, MD, USA, 2009.

27. Chen, J.; Ying, G.G.; Deng, W.J. Antibiotic residues in food: Extraction, analysis, and human health concerns. J. Agric. Food Chem. 2019, 67, 7569-7586. [CrossRef] [PubMed]

28. Ferrara, A.; Dos Santos, C.; Cimbro, M.; Grassi, G.G. Comparative antimicrobial activity and post-antibiotic effect of azithromycin, clarithromycin and roxithromycin against some respiratory pathogens. Int. J. Antimicrob. Agents 1996, 7, 181-186. [CrossRef]

29. Zhang, M.Q.; Chen, B.; Zhang, J.P.; Chen, N.; Liu, C.Z.; Hu, C.Q. Liver toxicity of macrolide antibiotics in zebrafish. Toxicology 2020, 441, 152501. [CrossRef] [PubMed]

30. Mingeot-Leclercq, M.P.; Glupczynski, Y.; Tulkens, P.M. Aminoglycosides: Activity and resistance. Antimicrob. Agents Chemother. 1999, 43, 727-737. [CrossRef] [PubMed]

31. Dowling, P.M. Miscellaneous antimicrobials: Ionophores, nitrofurans, nitroimidazoles, rifamycins, oxazolidones, and others. In Antimicrobial Therapy in Veterinary Medicine; Giguere, S., Prescott, J.F., Baggot, J.D., Walker, R.D., Dowling, P.M., Eds.; Blackwell Publishing: Ames, IA, USA, 2006; pp. 285-300.

32. Petersen, L.; Rogers, C. Aminoglycoside-induced hearing deficits-A review of cochlear ototoxicity. S. Afr. Fam. Pract. 2015, 57, 77-82. [CrossRef]

33. Black, F.O.; Pesznecker, S.; Stallings, V. Permanent gentamicin vestibulotoxicity. Otol. Neurotol. 2004, 25, 559-569. [CrossRef]

34. Blagburn, B.L.; Lindsay, D.S. Ectoparasiticides. In Veterinary Pharmacology and Therapeutics; Adams, H.R., Ed.; Iowa State University Press: Ames, IA, USA, 2001; pp. 1017-1039.

35. Martinez, M.; Mcdermott, P.; Walker, R. Pharmacology of the fluoroquinolones: A perspective for the use in domestic animals. Vet. J. 2006, 172, 10-28. [CrossRef] [PubMed]

36. Andersson, M.I.; Macgowan, A.P. Development of the quinolones. J. Antimicrob. Chemother. 2003, 51 (Suppl. 1), 1-11. [CrossRef]

37. Heeb, S.; Fletcher, M.P.; Chhabra, S.R.; Diggle, S.P.; Williams, P.; Camara, M. Quinolones: From antibiotics to autoinducers. FEMS Microbiol. Rev. 2011, 35, 247-274. [CrossRef]

38. De Sarro, A.; De Sarro, G. Adverse reactions to fluoroquinolones. An overview on mechanistic aspects. Curr. Med. Chem. 2001, 8, 371-384. [CrossRef] [PubMed]

39. Chopra, I.; Roberts, M. Tetracycline antibiotics: Mode of action, applications, molecular biology, and epidemiology of bacterial resistance. Microbiol. Mol. Biol. Rev. 2001, 65, 232-260. [CrossRef] [PubMed]

40. Bishop, Y. The Veterinary Formulary; Pharmaceutical Press: London, UK, 2001.

41. Chopra, I.; Hawkey, P.M.; Hinton, M. Tetracyclines, molecular and clinical aspects. J. Antimicrob. Chemother. 1992, $29,245-277$. [CrossRef] [PubMed]

42. Amacher, D.E.; Martin, B.A. Tetracycline-induced steatosis in primary canine hepatocyte cultures. Fundam. Appl. Toxicol. 1997, 40, 256-263. [CrossRef] [PubMed]

43. Ekwall, B.; Acosta, D. In vitro comparative toxicity of selected drugs and chemicals in HeLa cells, Chang liver cells, and rat hepatocytes. Drug Chem. Toxicol. 1982, 5, 219-231. [CrossRef] [PubMed]

44. Maffioli, S.I. A chemist's survey of different antibiotic classes. In Antibiotics: Targets, Mechanisms and Resistance; Gualerzi, C.O., Brandi, L., Fabbretti, A., Pon, C.L., Eds.; Wiley-VCH: Weinheim, Germany, 2014; pp. 1-22.

45. Tenson, T.; Lovmar, M.; Ehrenberg, M. The mechanism of action of macrolides, lincosamides and streptogramin B reveals the nascent peptide exit path in the ribosome. J. Mol. Biol. 2003, 330, 1005-1014. [CrossRef]

46. Spizek, J.; Rezanka, T. Lincosamides: Chemical structure, biosynthesis, mechanism of action, resistance, and applications. Biochem. Pharmacol. 2017, 133, 20-28. [CrossRef] [PubMed]

47. FAO/WHO. Toxicological Evaluation of Certain Veterinary Drug Residues in Food (Series 45); Joint FAO/WHO Expert Committee on Food Additives (JEFCA); World Health Organization: Geneva, Switzerland, 2000.

48. Henry, R.J. The mode of action of sulfonamides. Bacteriol. Rev. 1943, 7, 175-262. [CrossRef]

49. Madigan, M.T.; Martinko, J.M.; Bender, K.S.; Buckley, D.H.; Stahl, D.A. Brock Biology of Microorganisms; Pearson Education Limited: Boston, MA, USA, 2012.

50. Slatore, C.G.; Tilles, S.A. Sulfonamide hypersensitivity. Immunol. Allergy Clin. 2004, 24, 477-490. [CrossRef]

51. Knowles, S.; Shapiro, L.; Shear, N.H. Should celecoxib be contraindicated in patients who are allergic to sulfonamides? Revisiting the meaning of 'sulfa' allergy. Drug Saf. 2001, 24, 239-247. [CrossRef]

52. Goetting, V.; Lee, K.A.; Tell, L.A. Pharmacokinetics of veterinary drugs in laying hens and residues in eggs: A review of the literature. J. Vet. Pharmacol. Ther. 2011, 34, 521-556. [CrossRef]

53. Edwards, D.I. Nitroimidazole drugs-action and resistance mechanisms. I. Mechanisms of action. J. Antimicrob. Chemother. 1993, 31, 9-20. [CrossRef] [PubMed]

54. Botsoglou, N.A.; Fletouris, D.J. Drug Residues in Food; Marcel Dekker: New York, NY, USA, 2001. 
55. Tang, Y.Y.; Lu, H.F.; Lin, H.Y.; Shih, Y.C.; Hwang, D.F. Multiclass analysis of 23 veterinary drugs in milk by ultraperformance liquid chromatography-electrospray tandem mass spectrometry. J. Chromatogr. B Anal. Technol. Biomed. Life Sci. 2012, 881-882, 12-19. [CrossRef] [PubMed]

56. Chung, S.W.C.; Lam, C.H. Development of a 15-class multiresidue method for analyzing 78 hydrophilic and hydrophobic veterinary drugs in milk, egg and meat by liquid chromatography-tandem mass spectrometry. Anal. Methods 2015, 7, 6764-6776. [CrossRef]

57. Biselli, S.; Schwalb, U.; Meyer, A.; Hartig, L. A multi-class, multi-analyte method for routine analysis of 84 veterinary drugs in chicken muscle using simple extraction and LC-MS/MS. Food Addit. Contam. Part. A 2013, 30, 921-939. [CrossRef]

58. Dasenaki, M.E.; Thomaidis, N.S. Multi-residue determination of 115 veterinary drugs and pharmaceutical residues in milk powder, butter, fish tissue and eggs using liquid chromatography-tandem mass spectrometry. Anal. Chim. Acta 2015, 880, 103-121. [CrossRef]

59. Danezis, G.P.; Anagnostopoulos, C.J.; Liapis, K.; Koupparis, M.A. Multi-residue analysis of pesticides, plant hormones, veterinary drugs and mycotoxins using HILIC chromatography-MS/MS in various food matrices. Anal. Chim. Acta 2016, 942, 121-138. [CrossRef] [PubMed]

60. Xie, X.; Wang, B.; Pang, M.; Zhao, X.; Xie, K.; Zhang, Y.; Wang, Y.; Guo, Y.; Liu, C.; Bu, X.; et al. Quantitative analysis of chloramphenicol, thiamphenicol, florfenicol and florfenicol amine in eggs via liquid chromatography-electrospray ionization tandem mass spectrometry. Food Chem. 2018, 269, 542-548. [CrossRef]

61. Wang, B.; Liu, J.; Zhao, X.; Xie, K.; Diao, Z.; Zhang, G.; Zhang, T.; Dai, G. Determination of eight coccidiostats in eggs by liquid-liquid extraction-solid-phase extraction and liquid chromatography-tandem mass spectrometry. Molecules 2020, $25,987$. [CrossRef]

62. Kaufmann, A.; Butcher, P.; Maden, K.; Walker, S.; Widmer, M. Development of an improved high resolution mass spectrometry based multi-residue method for veterinary drugs in various food matrices. Anal. Chim. Acta 2011, 700, 86-94. [CrossRef]

63. Dasenaki, M.E.; Bletsou, A.A.; Koulis, G.A.; Thomaidis, N.S. Qualitative multiresidue screening method for 143 veterinary drugs and pharmaceuticals in milk and fish tissue using liquid chromatography quadrupole-time-of-flight mass spectrometry. J. Agric. Food Chem. 2015, 63, 4493-4508. [CrossRef] [PubMed]

64. Turnipseed, S.B.; Storey, J.M.; Lohne, J.J.; Andersen, W.C.; Burger, R.; Johnson, A.S.; Madson, M.R. Wide-scope screening method for multiclass veterinary drug residues in fish, shrimp, and eel using liquid chromatography-quadrupole high-resolution mass spectrometry. J. Agric. Food Chem. 2017, 65, 7252-7267. [CrossRef] [PubMed]

65. Xie, J.; Peng, T.; Zhu, A.; He, J.; Chang, Q.; Hu, X.; Chen, H.; Fan, C.; Jiang, W.; Chen, M.; et al. Multi-residue analysis of veterinary drugs, pesticides and mycotoxins in dairy products by liquid chromatography-tandem mass spectrometry using low-temperature cleanup and solid phase extraction. J. Chromatogr. B 2015, 1002, 19-29. [CrossRef] [PubMed]

66. Dasenaki, M.E.; Michali, C.S.; Thomaidis, N.S. Analysis of 76 veterinary pharmaceuticals from 13 classes including aminoglycosides in bovine muscle by hydrophilic interaction liquid chromatography-tandem mass spectrometry. J. Chromatogr. A 2016, 1452, 67-80. [CrossRef]

67. Han, R.W.; Zheng, N.; Yu, Z.N.; Wang, J.; Xu, X.M.; Qu, X.Y.; Li, S.L.; Zhang, Y.D.; Wang, J.Q. Simultaneous determination of 38 veterinary antibiotic residues in raw milk by UPLC-MS/MS. Food Chem. 2015, 181, 119-126. [CrossRef]

68. Piatkowska, M.; Jedziniak, P.; Zmudzki, J. Multiresidue method for the simultaneous determination of veterinary medicinal products, feed additives and illegal dyes in eggs using liquid chromatography-tandem mass spectrometry. Food Chem. 2016, 197, 571-580. [CrossRef]

69. Richter, B.E.; Jones, B.A.; Ezzell, J.L.; Porter, N.L.; Avdalovic, N.; Pohl, C. Accelerated solvent extraction: A technique for sample preparation. Anal. Chem. 1996, 68, 1033-1039. [CrossRef]

70. USEPA. Pressurised Fluid Extraction. In Test Methods for Evaluating Solid Waste; Method 3545; USEPA: Washington, DC, USA, 1995.

71. Tao, Y.; Yu, G.; Chen, D.; Pan, Y.; Liu, Z.; Wei, H.; Peng, D.; Huang, L.; Wang, Y.; Yuan, Z. Determination of 17 macrolide antibiotics and avermectins residues in meat with accelerated solvent extraction by liquid chromatography-tandem mass spectrometry. $J$. Chromatogr. B 2012, 897, 64-71. [CrossRef]

72. Yu, H.; Tao, Y.; Chen, D.; Wang, Y.; Yuan, Z. Development of an HPLC-UV method for the simultaneous determination of tetracyclines in muscle and liver of porcine, chicken and bovine with accelerated solvent extraction. Food Chem. 2011, 124, 1131-1138. [CrossRef]

73. Anastassiades, M.; Lehotay, S.J.; Štajnbaher, D.; Schenck, F.J. Fast and easy multiresidue method employing acetonitrile extraction/partitioning and "dispersive solid-phase extraction" for the determination of pesticide residues in produce. J. AOAC Int. 2003, 86, 412-431. [CrossRef]

74. Xu, X.; Xu, X.; Han, M.; Qiu, S.; Hou, X. Development of a modified QuEChERS method based on magnetic multiwalled carbon nanotubes for the simultaneous determination of veterinary drugs, pesticides and mycotoxins in eggs by UPLC-MS/MS. Food Chem. 2019, 276, 419-426. [CrossRef]

75. Arias, J.L.O.; Schneider, A.; Batista-Andrade, J.A.; Vieira, A.A.; Caldas, S.S.; Primel, E.G. Chitosan from shrimp shells: A renewable sorbent applied to the clean-up step of the QuEChERS method in order to determine multi-residues of veterinary drugs in different types of milk. Food Chem. 2018, 240, 1243-1253. [CrossRef] 
76. Zhang, Y.; Liu, X.; Li, X.; Zhang, J.; Cao, Y.; Su, M.; Shi, Z.; Sun, H. Rapid screening and quantification of multi-class multiresidue veterinary drugs in royal jelly by ultra performance liquid chromatography coupled to quadrupole time-of-flight mass spectrometry. Food Control. 2016, 60, 667-676. [CrossRef]

77. Shin, D.; Kang, H.S.; Jeong, J.; Kim, J.; Choe, W.J.; Lee, K.S.; Rhee, G.S. Multi-residue determination of veterinary drugs in fishery products using liquid chromatography-tandem mass spectrometry. Food Anal. Methods 2018, 11, 1815-1831. [CrossRef]

78. Freitas, S.K.B.; Paim, A.P.S.; Silva, P.T.D.S. Development of a LC-IT-TOF MS procedure to quantify veterinary drug residues in milk employing a QuEChERS approach. Food Anal. Methods 2013, 7, 39-46. [CrossRef]

79. Villar-Pulido, M.; Gilbert-Lopez, B.; Garcia-Reyes, J.F.; Martos, N.R.; Molina-Diaz, A. Multiclass detection and quantitation of antibiotics and veterinary drugs in shrimps by fast liquid chromatography time-of-flight mass spectrometry. Talanta 2011, 85, 1419-1427. [CrossRef] [PubMed]

80. Kang, J.; Fan, C.L.; Chang, Q.Y.; Bu, M.N.; Zhao, Z.Y.; Wang, W.; Pang, G.F. Simultaneous determination of multi-class veterinary drug residues in different muscle tissues by modified QuEChERS combined with HPLC-MS/MS. Anal. Methods 2014, 6, 6285. [CrossRef]

81. Nakajima, T.; Nagano, C.; Sasamoto, T.; Hayashi, H.; Kanda, M.; Kanai, S.; Takeba, K.; Matsushima, Y.; Takano, I. Development and validation of rapid analysis method for multi-class veterinary drugs in livestock products by LC-MS/MS. J. Food Hyg. Soc. Jpn. 2012, 53, 243-253. [CrossRef]

82. Barker, S.A.; Long, A.R.; Short, C.R. Isolation of drug residues from tissues by solid phase dispersion. J. Chromatogr. A 1989, 475, 353-361. [CrossRef]

83. Pérez, R.A.; Albero, B.; Tadeo, J.L. Book chapter: 19-Matrix solid phase dispersion. In A Volume in Handbooks in Separation Science; Elsevier: Madrid, Spain, 2020; pp. 531-549. [CrossRef]

84. Wang, G.N.; Zhang, L.; Song, Y.P.; Liu, J.X.; Wang, J.P. Application of molecularly imprinted polymer based matrix solid phase dispersion for determination of fluoroquinolones, tetracyclines and sulfonamides in meat. J. Chromatogr. B 2017, 1065-1066, 104-111. [CrossRef]

85. Shen, Q.; Jin, R.; Xue, J.; Lu, Y.; Dai, Z. Analysis of trace levels of sulfonamides in fish tissue using micro-scale pipette tip-matrix solid-phase dispersion and fast liquid chromatography tandem mass spectrometry. Food Chem. 2016, 194, 508-515. [CrossRef]

86. Tao, Y.; Zhu, F.; Chen, D.; Wei, H.; Pan, Y.; Wang, X.; Liu, Z.; Huang, L.; Wang, Y.; Yuan, Z. Evaluation of matrix solid-phase dispersion (MSPD) extraction for multi-fenicols determination in shrimp and fish by liquid chromatography-electrospray ionisation tandem mass spectrometry. Food Chem. 2014, 150, 500-506. [CrossRef]

87. Da Silva, M.C.; Orlando, R.M.; Faria, A.F. Electrical field assisted matrix solid phase dispersion as a powerful tool to improve the extraction efficiency and clean-up of fluoroquinolones in bovine milk. J. Chromatogr. A 2016, 1461, 27-34. [CrossRef]

88. Mu, G.; Liu, H.; Xu, L.; Tian, L.; Luan, F. Matrix solid-phase dispersion extraction and capillary electrophoresis determination of tetracycline residues in milk. Food Anal. Methods 2011, 5, 148-153. [CrossRef]

89. Huang, Z.; Pan, X.D.; Huang, B.F.; Xu, J.J.; Wang, M.L.; Ren, Y.P. Determination of $15 \beta$-lactam antibiotics in pork muscle by matrix solid-phase dispersion extraction (MSPD) and ultra-high pressure liquid chromatography tandem mass spectrometry. Food Control. 2016, 66, 145-150. [CrossRef]

90. Capriotti, A.L.; Cavaliere, C.; Laganà, A.; Piovesana, S.; Samperi, R. Recent trends in matrix solid-phase dispersion. TrAC Trends Anal. Chem. 2013, 43, 53-66. [CrossRef]

91. Capriotti, A.L.; Cavaliere, C.; Foglia, P.; Samperi, R.; Stampachiacchiere, S.; Ventura, S.; Laganà, A. Recent advances and developments in matrix solid-phase dispersion. TrAC Trends Anal. Chem. 2015, 71, 186-193. [CrossRef]

92. Chico, J.; Rubies, A.; Centrich, F.; Companyo, R.; Prat, M.D.; Granados, M. Use of gel permeation chromatography for clean-up in the analysis of coccidiostats in eggs by liquid chromatography-tandem mass spectrometry. Anal. Bioanal. Chem. 2013, 405, 4777-4786. [CrossRef]

93. Aguilera-Luiz, M.M.; Romero-Gonzalez, R.; Plaza-Bolanos, P.; Vidal, J.L.; Frenich, A.G. Rapid and semiautomated method for the analysis of veterinary drug residues in honey based on turbulent-flow liquid chromatography coupled to ultrahigh-performance liquid chromatography-Orbitrap mass spectrometry (TFC-UHPLC-Orbitrap-MS). J. Agric. Food Chem. 2013, 61, 829-839. [CrossRef] [PubMed]

94. Samanidou, V.; Galanopoulos, L.D.; Kabir, A.; Furton, K.G. Fast extraction of amphenicols residues from raw milk using novel fabric phase sorptive extraction followed by high-performance liquid chromatography-diode array detection. Anal. Chim. Acta 2015, 855, 41-50. [CrossRef] [PubMed]

95. Lu, Y.; Lu, L.; He, J.; Zhao, T. Preparation of hydrophilic molecularly imprinted solid-phase microextraction fiber for the selective removal and extraction of trace tetracyclines residues in animal derived foods. J. Sep. Sci. 2020, 43, 2172-2179. [CrossRef] [PubMed]

96. Charitonos, S.; Samanidou, V.F.; Papadoyannis, I. Development of an HPLC-DAD method for the determination of five sulfonamides in shrimps and validation according to the European decision 657/2002/EC. Food Anal. Methods 2017, 10, 2011-2017. [CrossRef]

97. Tajabadi, F.; Ghambarian, M.; Yamini, Y.; Yazdanfar, N. Combination of hollow fiber liquid phase microextraction followed by HPLC-DAD and multivariate curve resolution to determine antibacterial residues in foods of animal origin. Talanta 2016, 160, 400-409. [CrossRef] [PubMed] 
98. Mookantsa, S.O.; Dube, S.; Nindi, M.M. Development and application of a dispersive liquid-liquid microextraction method for the determination of tetracyclines in beef by liquid chromatography mass spectrometry. Talanta 2016, 148, 321-328. [CrossRef] [PubMed]

99. Mor, F.; Kocasari, F.S.; Ozdemir, G.; Oz, B. Determination of sulphonamide residues in cattle meats by the Charm-II system and validation with high performance liquid chromatography with fluorescence detection. Food Chem. 2012, 134, 1645-1649. [CrossRef] [PubMed]

100. Wang, B.; Xie, X.; Zhao, X.; Xie, K.; Diao, Z.; Zhang, G.; Zhang, T.; Dai, G. Development of an accelerated solvent extraction-ultraperformance liquid chromatography-fluorescence detection method for quantitative analysis of thiamphenicol, florfenicol and florfenicol amine in poultry eggs. Molecules 2019, 24, 1830. [CrossRef]

101. Yu, H.; Mu, H.; Hu, Y.M. Determination of fluoroquinolones, sulfonamides, and tetracyclines multiresidues simultaneously in porcine tissue by MSPD and HPLC-DAD. J. Pharm. Anal. 2012, 2, 76-81. [CrossRef] [PubMed]

102. Evaggelopoulou, E.N.; Samanidou, V.F. Development and validation of an HPLC method for the determination of six penicillin and three amphenicol antibiotics in gilthead seabream (Sparus Aurata) tissue according to the European Union Decision 2002/657/EC. Food Chem. 2013, 136, 1322-1329. [CrossRef]

103. Kim, B.J.; Ham, H.S.; Lee, J.J.; Cheong, N.Y.; Myung, S.W. Determination of coccidiostats (Amprolium and Decoquinate) in cattle and chicken's muscle using high performance liquid chromatography. Bull. Korean Chem. Soc. 2012, 33, 559-563. [CrossRef]

104. Chitescu, C.L.; Nicolau, A.I.; Csuma, A.; Moisoiu, C. Simultaneous analysis of four sulfonamides in chicken muscle tissue by HPLC. Food Addit. Contam. A 2011, 28, 1013-1020. [CrossRef] [PubMed]

105. Negarian, M.; Mohammadinejad, A.; Mohajeri, S.A. Preparation, evaluation and application of core-shell molecularly imprinted particles as the sorbent in solid-phase extraction and analysis of lincomycin residue in pasteurized milk. Food Chem. 2019, 288, 29-38. [CrossRef] [PubMed]

106. Ibrahim, F.A.; Nasr, J.J.M. Direct determination of ampicillin and amoxicillin residues in food samples after aqueous SDS extraction by micellar liquid chromatography with UV detection. Anal. Methods 2014, 6, 1523-1529. [CrossRef]

107. Lv, Y.K.; Zhang, J.Q.; Guo, Z.Y.; Zhang, W.; Sun, H.W. Determination of tetracyclines residues in egg, milk, and milk powder by online coupling of a precolumn packed with molecular imprinted hybrid composite materials to RP-HPLC-UV. J. Liq. Chromatogr. Relat. Technol. 2014, 38, 1-7. [CrossRef]

108. Zhou, Y.; Liu, H.; Li, J.; Sun, Z.; Cai, T.; Wang, X.; Zhao, S.; Gong, B. Restricted access magnetic imprinted microspheres for directly selective extraction of tetracycline veterinary drugs from complex samples. J. Chromatogr. A 2020, 1613, 460684. [CrossRef]

109. Karimi, M.; Aboufazeli, F.; Zhad, H.R.L.Z.; Sadeghi, O.; Najafi, E. Determination of sulfonamides in chicken meat by magnetic molecularly imprinted polymer coupled to HPLC-UV. Food Anal. Methods 2013, 7, 73-80. [CrossRef]

110. Hui, W.; Li, Q.; Ma, H.; Wu, M.; Feng, K.; Zhu, H.; Yang, P.; Li, J.; Chen, C.; Yan, K. Rapid screening for 15 sulfonamide residues in foods of animal origin by high-performance liquid chromatography-UV method. J. Chromatogr. Sci. 2018, 56, 636-643. [CrossRef]

111. Liu, Q.; Li, J.; Song, X.; Zhang, M.; Li, E.; Gao, F.; He, L. Simultaneous determination of aminoglycoside antibiotics in feeds using high performance liquid chromatography with evaporative light scattering detection. RSC Adv. 2017, 7, 1251-1259. [CrossRef]

112. Marazuela, M.D. Determination of veterinary drug residues in foods by liquid chromatography-mass spectrometry: Basic and cutting-edge applications. In Liquid Chromatography; Fanali, S., Haddad, P.R., Poole, C.F., Riekkola, M.L., Eds.; Elsevier: Madrid, Spain, 2017; pp. 539-570.

113. Delatour, T.; Racault, L.; Bessaire, T.; Desmarchelier, A. Screening of veterinary drug residues in food by LC-MS/MS. Background and challenges. Food Addit. Contam. A 2018, 35, 632-645. [CrossRef]

114. Xu, Y.; Ding, J.; Chen, H.; Zhao, Q.; Hou, J.; Yan, J.; Wang, H.; Ding, L.; Ren, N. Fast determination of sulfonamides from egg samples using magnetic multiwalled carbon nanotubes as adsorbents followed by liquid chromatography-tandem mass spectrometry. Food Chem. 2013, 140, 83-90. [CrossRef] [PubMed]

115. Wang, B.; Pang, M.; Xie, X.; Zhao, M.; Xie, K.; Zhang, Y.; Zhao, X.; Wang, Y.J.; Wang, R.; Wu, H.; et al. Quantitative analysis of amoxicillin, amoxicillin major metabolites, and ampicillin in chicken tissues via ultra-performance liquid chromatographyelectrospray ionization tandem mass spectrometry. Food Anal. Methods 2017, 10, 3292-3305. [CrossRef]

116. Anumol, T.; Lehotay, S.J.; Stevens, J.; Zweigenbaum, J. Comparison of veterinary drug residue results in animal tissues by ultrahigh-performance liquid chromatography coupled to triple quadrupole or quadrupole-time-of-flight tandem mass spectrometry after different sample preparation methods, including use of a commercial lipid removal product. Anal. Bioanal. Chem. 2017, 409, 2639-2653. [CrossRef]

117. Tao, Y.; Chen, D.; Yu, G.; Yu, H.; Pan, Y.; Wang, Y.; Huang, L.; Yuan, Z. Simultaneous determination of lincomycin and spectinomycin residues in animal tissues by gas chromatography-nitrogen phosphorus detection and gas chromatography-mass spectrometry with accelerated solvent extraction. Food Addit. Contam. A 2011, 28, 145-154. [CrossRef] [PubMed]

118. Caban, M.; Haliński, Ł.; Kumirska, J.; Stepnowski, P. Gas chromatography applied to the analysis of drug and veterinary drug residues in food, environmental, and biological samples. In Determination of Target Xenobiotics and Unknown Compound Residues in Food, Environmental, and Biological Samples; Sherma, J., Tuzimski, T., Eds.; CRC Press: Boca Raton, FL, USA, 2018 ; pp. $133-166$.

119. Wang, B.; Pang, M.; Xie, X.; Xie, K.; Zhang, Y.; Cui, L.; Zhao, X.; Wang, Y.; Shi, H.; Guo, Y.; et al. Quantification of piperazine in chicken and pig tissues by gas chromatography-electron ionization tandem mass spectrometry employing pre-column derivatization with acetic anhydride. J. Chromatogr. A 2017, 1519, 9-18. [CrossRef] [PubMed] 
120. Wang, J.; Leung, D.; Chow, W.; Chang, J.; Wong, J.W. Development and validation of a multiclass method for analysis of veterinary drug residues in milk using ultrahigh performance liquid chromatography electrospray ionization quadrupole orbitrap mass spectrometry. J. Agric. Food Chem. 2015, 63, 9175-9187. [CrossRef]

121. Song, X.; Zhou, T.; Li, J.; Su, Y.; Xie, J.; He, L. Determination of macrolide antibiotics residues in pork using molecularly imprinted dispersive solid-phase extraction coupled with LC-MS/MS. J. Sep. Sci. 2018, 41, 1138-1148. [CrossRef]

122. Tao, Y.; Chen, D.; Yu, H.; Huang, L.; Liu, Z.; Cao, X.; Yan, C.; Pan, Y.; Liu, Z.; Yuan, Z. Simultaneous determination of 15 aminoglycoside(s) residues in animal derived foods by automated solid-phase extraction and liquid chromatography-tandem mass spectrometry. Food Chem. 2012, 135, 676-683. [CrossRef] [PubMed]

123. Stoilova, N.; Surleva, A.; Stoev, G. Determination of quinolonones in food of animal origin by liquid chromatography coupled with fluorescence and mass spectrometric detection. Acta Chromatogr. 2014, 26, 599-614. [CrossRef]

124. Juan, C.; Moltó, J.C.; Mañes, J.; Font, G. Determination of macrolide and lincosamide antibiotics by pressurised liquid extraction and liquid chromatography-tandem mass spectrometry in meat and milk. Food Control. 2010, 21, 1703-1709. [CrossRef]

125. Shen, J.; Xia, X.; Jiang, H.; Li, C.; Li, J.; Li, X.; Ding, S. Determination of chloramphenicol, thiamphenicol, florfenicol, and florfenicol amine in poultry and porcine muscle and liver by gas chromatography-negative chemical ionization mass spectrometry. $J$. Chromatogr. B 2009, 877, 1523-1529. [CrossRef]

126. Yikilmaz, Y.; Filazi, A. Detection of florfenicol residues in salmon trout via GC-MS. Food Anal. Methods 2014, 8, 1027-1033. [CrossRef]

127. Xue, L.C.; Cai, Q.R.; Zheng, X.; Liu, L.; Ling, Y.H.; Li, Z.; Peng, Y.F.; Chen, J.; Cai, D.L.; Cai, J.; et al. Determination of 9 hydroxy veterinary drug residues in fish by QuEChERS-GPC-GC/MS. J. Chin. Mass Spectrom. Soc. 2017, 38, 655-663. [CrossRef]

128. Zhao, X.; Wang, B.; Xie, K.; Liu, Y.; Zhang, Y.; Wang, Y.; Guo, Y.; Bu, X.; Liu, C.; Zhang, G.; et al. Determination of dinitolmide and its metabolite 3-ANOT in chicken tissues via ASE-SPE-GC-MS/MS. J. Food Compos. Anal. 2018, 71, 94-103. [CrossRef]

129. Zhao, X.; Wang, B.; Xie, K.; Liu, Y.; Zhang, Y.; Wang, Y.; Liu, C.; Guo, Y.; Bu, X.; Zhang, G.; et al. Development of an ASE-GC-MS/MS method for detecting dinitolmide and its metabolite 3-ANOT in eggs. J. Mass Spectrom. 2018, 53, 976-985. [CrossRef]

130. An, L.; Wang, Y.; Pan, Y.; Tao, Y.; Chen, D.; Liu, Z.; Yang, W.; Peng, D.; Yuan, Z. Development and validation of a sensitive indirect competitive enzyme-linked immunosorbent assay for the screening of florfenicol and thiamphenicol in edible animal tissue and feed. Food Anal. Methods 2016, 9, 2434-2443. [CrossRef]

131. Cao, S.; Song, S.; Liu, L.; Kong, N.; Kuang, H.; Xu, C. Comparison of an enzyme-linked immunosorbent assay with an immunochromatographic assay for detection of lincomycin in milk and honey. Immunol. Investig. 2015, 44, 438-450. [CrossRef]

132. Wang, Z.; Mi, T.; Beier, R.C.; Zhang, H.; Sheng, Y.; Shi, W.; Zhang, S.; Shen, J. Hapten synthesis, monoclonal antibody production and development of a competitive indirect enzyme-linked immunosorbent assay for erythromycin in milk. Food Chem. 2015, 171, 98-107. [CrossRef] [PubMed]

133. Tian, W.; Zhang, X.; Song, M.; Jiang, H.; Ding, S.; Shen, J.; Li, J. An enzyme-linked immunosorbent assay to detect salinomycin residues based on immunomagnetic bead clean-up. Food Anal. Methods 2017, 10, 3042-3051. [CrossRef]

134. Zhou, Q.; Peng, D.; Wang, Y.; Pan, Y.; Wan, D.; Zhang, X.; Yuan, Z. A novel hapten and monoclonal-based enzyme-linked immunosorbent assay for sulfonamides in edible animal tissues. Food Chem. 2014, 154, 52-62. [CrossRef] [PubMed]

135. Bahmani, K.; Shahbazi, Y.; Nikousefat, Z. Monitoring and risk assessment of tetracycline residues in foods of animal origin. Food Sci. Biotechnol. 2020, 29, 441-448. [CrossRef]

136. Jiang, W.; Wang, Z.; Beier, R.C.; Jiang, H.; Wu, Y.; Shen, J. Simultaneous determination of 13 fluoroquinolone and 22 sulfonamide residues in milk by a dual-colorimetric enzyme-linked immunosorbent assay. Anal. Chem. 2013, 85, 1995-1999. [CrossRef] [PubMed]

137. Solomun, B.; Bilandzic, N.; Varenina, I.; Scortichini, G. Validation of an enzyme-linked immunosorbent assay for qualitative screening of neomycin in muscle, liver, kidney, eggs and milk. Food Addit. Contam. A 2011, 28, 11-18. [CrossRef]

138. Jiao, S.N.; Liu, J.; Zhang, Y.F.; Zhao, G.X.; Wang, J.P. Preparation of a bi-hapten antigen and the broad-specific antibody for simultaneous immunoassay of penicillins and tetracyclines in milk. Food Agric. Immunol. 2012, 23, 273-287. [CrossRef]

139. Wei, D.; Meng, H.; Zeng, K.; Huang, Z. Visual dual dot immunoassay for the simultaneous detection of kanamycin and streptomycin in milk. Anal. Methods 2019, 11, 70-77. [CrossRef]

140. European Commission Commission decision 2002/657/EC of 12 august 2002 implementing council directive 96/23/EC concerning the performance of analytical methods and the interpretation of results. Off. J. Eur. Commun. 2002, 50, 8-36.

141. El-Attug, M.N.; Adams, E.; Hoogmartens, J.; Van Schepdael, A. Capacitively coupled contactless conductivity detection as an alternative detection mode in CE for the analysis of kanamycin sulphate and its related substances. J. Sep. Sci. 2011, 34, 2448-2454. [CrossRef] [PubMed]

142. Donegatti, T.A.; Lobato, A.; Duek, E.A.R.; Goncalves, L.M.; Alves Pereira, E. Derivatization-free determination of aminoglycosides by CZE-UV in pharmaceutical formulations. Electrophoresis 2020, 41, 1576-1583. [CrossRef]

143. Li, Z.; Li, Y.; Qi, M.; Zhong, S.; Wang, W.; Wang, A.J.; Chen, J. Graphene-Fe3 O4 as a magnetic solid-phase extraction sorbent coupled to capillary electrophoresis for the determination of sulfonamides in milk. J. Sep. Sci. 2016, 39, 3818-3826. [CrossRef]

144. Shuo, Z.; Hao-Tian, W.; Ke, L.I.; Jing, Z.; Xia-Yan, W.; Guang-Sheng, G.U.O. Fast determination of residual sulfonamides in milk by in-tube solid-phase microextraction coupled with capillary electrophoresis-laser induced fluorescence. Chin. J. Anal. Chem. 2018, 46, e1810-e1816. [CrossRef] 
145. Liu, Y.M.; Yang, Y.; Li, J.; Peng, L.F.; Mei, L. A validated method for the sensitive determination of macrolide antibiotics by capillary electrophoresis with electrochemiluminescence detection and its applications. Curr. Anal. Chem. 2011, 7, 325-332. [CrossRef]

146. Ibarra, I.S.; Rodriguez, J.A.; Paez-Hernandez, M.E.; Santos, E.M.; Miranda, J.M. Determination of quinolones in milk samples using a combination of magnetic solid-phase extraction and capillary electrophoresis. Electrophoresis 2012, 33, 2041-2048. [CrossRef]

147. Moreno-Gonzalez, D.; Lara, F.J.; Gamiz-Gracia, L.; Garcia-Campana, A.M. Molecularly imprinted polymer as in-line concentrator in capillary electrophoresis coupled with mass spectrometry for the determination of quinolones in bovine milk samples. $J$. Chromatogr. A 2014, 1360, 1-8. [CrossRef]

148. Moreno-Gonzalez, D.; Lara, F.J.; Jurgovska, N.; Gamiz-Gracia, L.; Garcia-Campana, A.M. Determination of aminoglycosides in honey by capillary electrophoresis tandem mass spectrometry and extraction with molecularly imprinted polymers. Anal. Chim. Acta 2015, 891, 321-328. [CrossRef]

149. Dai, T.; Duan, J.; Li, X.; Xu, X.; Shi, H.; Kang, W. Determination of sulfonamide residues in food by capillary zone electrophoresis with on-line chemiluminescence detection based on an Ag(III) complex. Int. J. Mol. Sci. 2017, 18, 1286. [CrossRef] [PubMed]

150. Yang, S.; Ma, S.; Zhu, K.; Wang, M.; Li, J.; Arabi, M.; Liu, H.; Li, Y.; Chen, L. Simultaneous enrichment/determination of six sulfonamides in animal husbandry products and environmental waters by pressure-assisted electrokinetic injection coupled with capillary zone electrophoresis. J. Food Compos. Anal. 2020, 88, 103462. [CrossRef]

151. Hu, X.; Yang, J.; Chen, C.; Khan, H.; Guo, Y.; Yang, L. Capillary electrophoresis-integrated immobilized enzyme microreactor utilizing single-step in-situ penicillinase-mediated alginate hydrogelation: Application for enzyme assays of penicillinase. Talanta 2018, 189, 377-382. [CrossRef] [PubMed]

152. Islas, G.; Rodriguez, J.A.; Perez-Silva, I.; Miranda, J.M.; Ibarra, I.S. Solid-phase extraction and large-volume sample stackingcapillary electrophoresis for determination of tetracycline residues in milk. J. Anal. Methods Chem. 2018, 2018, 5394527. [CrossRef]

153. Wang, N.; Su, M.; Liang, S.; Sun, H. Sensitive residue analysis of quinolones and sulfonamides in aquatic product by capillary zone electrophoresis using large-volume sample stacking with polarity switching combined with accelerated solvent extraction. Food Anal. Methods 2015, 9, 1020-1028. [CrossRef]

154. Ferreira, T.A.; Flores-Aguilar, J.F.; Santos, E.M.; Rodriguez, J.A.; Ibarra, I.S. New poly(ionic liquid) based fiber for determination of oxytetracycline in milk samples by application of SPME-CE technique. Molecules 2019, 24, 430. [CrossRef]

155. Li, M.H.; He, W.S.; Zhang, L.J.; Duan, C.L. Analysis of penicillin and its $\beta$-lactamase hydrolysis products in milk using capillary zone electrophoresis. Anal. Methods 2015, 7, 4602-4607. [CrossRef]

156. Moreno-Gonzalez, D.; Hamed, A.M.; Gilbert-Lopez, B.; Gamiz-Gracia, L.; Garcia-Campana, A.M. Evaluation of a multiresidue capillary electrophoresis-quadrupole-time-of-flight mass spectrometry method for the determination of antibiotics in milk samples. J. Chromatogr. A 2017, 1510, 100-107. [CrossRef]

157. Lorenzetti, A.S.; Lista, A.G.; Domini, C.E. Reverse ultrasound-assisted emulsification-microextraction of macrolides from chicken fat followed by electrophoretic determination. LWT 2019, 113, 108334. [CrossRef]

158. Chen, B.; Du, Y. Evaluation of the enantioseparation capability of the novel chiral selector clindamycin phosphate towards basic drugs by micellar electrokinetic chromatography. J. Chromatogr. A 2010, 1217, 1806-1812. [CrossRef] [PubMed]

159. Chen, Z.; Zhong, Z.; Xia, Z.; Yang, F.; Mu, X. Separation of fluoroquinolones by MEKC modified with hydrophobic ionic liquid as a modifier. Chromatographia 2011, 75, 65-70. [CrossRef]

160. Kowalski, P.; Konieczna, L.; Olędzka, I.; Plenis, A.; Baczek, T. Development and validation of electromigration technique for the determination of lincomycin and clindamycin residues in poultry tissues. Food Anal. Methods 2013, 7, 276-282. [CrossRef]

161. Belal, F.; El-Razeq, S.A.; Fouad, M.; Zayed, S.; Fouad, F. Simultaneous determination of five coccidiostats in veterinary powders, feed premixes, and baby food by micellar electrokinetic chromatography: Application to chicken tissues and liver. Food Anal. Methods 2018, 11, 3531-3541. [CrossRef]

162. Springer, V.H.; Lista, A.G. Micellar nanotubes dispersed electrokinetic chromatography for the simultaneous determination of antibiotics in bovine milk. Electrophoresis 2012, 33, 2049-2055. [CrossRef]

163. Kowalski, P.; Plenis, A.; Oledzka, I.; Konieczna, L. Optimization and validation of the micellar electrokinetic capillary chromatographic method for simultaneous determination of sulfonamide and amphenicol-type drugs in poultry tissue. J. Pharm. Biomed. Anal. 2011, 54, 160-167. [CrossRef]

164. Shao, Y.X.; Chen, G.H.; Fang, R.; Zhang, L.; Yi, L.X.; Meng, H.L. Analysis of six beta-lactam residues in milk and egg by micellar electrokinetic chromatography with large-volume sample stacking and polarity switching. J. Agric. Food Chem. 2016, 64, 3456-3461. [CrossRef] [PubMed]

165. Ge, L.; Liu, Q.; Hao, N.; Kun, W. Recent developments of photoelectrochemical biosensors for food analysis. J. Mater. Chem. B 2019, 7, 7283-7300. [CrossRef] [PubMed]

166. Cervera-Chiner, L.; Jiménez, Y.; Montoya, Á.; Juan-Borrás, M.; Pascual, N.; Arnau, A.; Escriche, I. High fundamental frequency quartz crystal microbalance (HFF-QCMD) immunosensor for detection of sulfathiazole in honey. Food Control. 2020, 115, 107296. [CrossRef]

167. Majdinasab, M.; Mitsubayashi, K.; Marty, J.L. Optical and electrochemical sensors and biosensors for the detection of quinolones. Trends Biotechnol. 2019, 37, 898-915. [CrossRef] [PubMed]

168. Jalalian, S.H.; Karimabadi, N.; Ramezani, M.; Abnous, K.; Taghdisi, S.M. Electrochemical and optical aptamer-based sensors for detection of tetracyclines. Trends Food Sci. Technol. 2018, 73, 45-57. [CrossRef] 
169. Sadeghi, A.S.; Ansari, N.; Ramezani, M.; Abnous, K.; Mohsenzadeh, M.; Taghdisi, S.M.; Alibolandi, M. Optical and electrochemical aptasensors for the detection of amphenicols. Biosens. Bioelectron. 2018, 118, 137-152. [CrossRef] [PubMed]

170. Kharewal, T.; Verma, N.; Gahlaut, A.; Hooda, V. Biosensors for penicillin quantification: A comprehensive review. Biotechnol. Lett. 2020, 42, 1829-1846. [CrossRef] [PubMed]

171. Mehlhorn, A.; Rahimi, P.; Joseph, Y. Aptamer-based biosensors for antibiotic detection: A review. Biosensors 2018, 8, 54. [CrossRef] [PubMed]

172. Wang, K.P.; Zhang, Y.C.; Zhang, X.; Shen, L. Green preparation of chlorine-doped graphene and its application in electrochemical sensor for chloramphenicol detection. SN Appl. Sci. 2019, 1, 157. [CrossRef]

173. Benvidi, A.; Yazdanparast, S.; Rezaeinasab, M.; Tezerjani, M.D.; Abbasi, S. Designing and fabrication of a novel sensitive electrochemical aptasensor based on poly (L-glutamic acid)/MWCNTs modified glassy carbon electrode for determination of tetracycline. J. Electroanal. Chem. 2018, 808, 311-320. [CrossRef]

174. Shi, X.; Ren, X.; Jing, N.; Zhang, J. Electrochemical determination of ampicillin based on an electropolymerized poly(ophenylenediamine)/gold nanoparticle/single-walled carbon nanotube modified glassy carbon electrode. Anal. Lett. 2020, 53, 2854-2867. [CrossRef]

175. Zhao, J.; Guo, W.; Pei, M.; Ding, F. GR-Fe3O4NPs and PEDOT-AuNPs composite based electrochemical aptasensor for the sensitive detection of penicillin. Anal. Methods 2016, 8, 4391-4397. [CrossRef]

176. Li, Z.; Liu, C.; Sarpong, V.; Gu, Z. Multisegment nanowire/nanoparticle hybrid arrays as electrochemical biosensors for simultaneous detection of antibiotics. Biosens. Bioelectron. 2019, 126, 632-639. [CrossRef]

177. Nie, R.; Xu, X.; Chen, Y.; Yang, L. Optical fiber-mediated immunosensor with a tunable detection range for multiplexed analysis of veterinary drug residues. ACS Sens. 2019, 4, 1864-1872. [CrossRef]

178. Ebarvia, B.S.; Ubando, I.E.; Sevilla, F.B. Biomimetic piezoelectric quartz crystal sensor with chloramphenicol-imprinted polymer sensing layer. Talanta 2015, 144, 1260-1265. [CrossRef] [PubMed]

179. Roushani, M.; Rahmati, Z.; Hoseini, S.J.; Fath, R.H. Impedimetric ultrasensitive detection of chloramphenicol based on aptamer MIP using a glassy carbon electrode modified by 3-ampy-RGO and silver nanoparticle. Colloids Surf. B Biointerfaces $2019,183,110451$. [CrossRef] [PubMed]

180. Caglayan, M.O. Aptamer-based ellipsometric sensor for ultrasensitive determination of aminoglycoside group antibiotics from dairy products. J. Sci. Food Agric. 2020, 100, 3386-3393. [CrossRef]

181. Ismail, F.; Adeloju, S.B.; Moline, A.N. Fabrication of a single layer and bilayer potentiometric biosensors for penicillin by galvanostatic entrapment of penicillinase into polypyrrole films. Electroanalysis 2014, 26, 2607-2618. [CrossRef] 